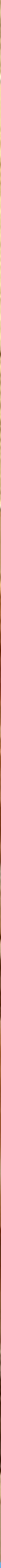

\title{
Pilot ten behoeve van substraatvoorkeur voor stofbadgedrag van leghennen
}





\section{Pilot ten behoeve van substraatvoorkeur voor stofbadgedrag van leghennen}

Jorine Rommers, Ingrid de Jong en Ellen van Weeghel

Dit onderzoek is uitgevoerd door Wageningen Livestock Research, in opdracht van en gefinancierd door de topsector Agri \& Food en Avined, binnen het project Ontwerpen voor een gezondere pluimveehouderij (MIP) (AF-16204).

Wageningen Livestock Research

Wageningen, juli 2020

Rapport 1264 
Rommers, J.M., I.C. de Jong, H.J.E. van Weeghel, 2020. Pilot ten behoeve van substraatvoorkeur voor stofbadgedrag van leghennen. Wageningen Livestock Research, Rapport 1264.

Samenvatting NL In een kortdurende pilotproef is onderzocht of leghennen een voorkeur vertonen om te stofbaden in kokosgruis, gemalen tarwestro, fijne houtvezels, of turf. Van turf is bekend dat het voldoet als stofbadsubstraat en daarom zijn de andere drie substraten hiermee vergeleken. De studie is uitgevoerd op een commercieel leghennenbedrijf waarin alle vier substraten tegelijkertijd in twee secties in het systeem werden aangeboden. Video opnames zijn gemaakt gedurende de middag, en geanalyseerd over een periode van vier dagen. Uit de eenvoudige pilotstudie bleek dat er evenveel leghennen stofbaden in kokosgruis en turf. Daarentegen werden gemalen tarwestro en fijne houtvezels nauwelijks gebruikt om in te stofbaden.

Summery UK In a simple and short-lasting pilot study it was determined whether laying hens prefer to dustbath in either small coconut fibres, grinded wheat straw, sawdust (fine) or peat moss. Peat moss has been included because it is a preferred dustbathing substrate for laying hens. The study was performed in two units on a commercial laying hen farm. In each unit, all four substrates were tested. Video recordings were made during the afternoon and analysed during four days. This pilot study indicated that an equal number of hens showed dustbathing in peat moss and coconut fibres, whereas grinded wheat straw and sawdust were hardly used for dustbathing.

Dit rapport is gratis te downloaden van https://doi.org/10.18174/528064 of op www.wur.nl/environmental-research (ga naar 'Wageningen Livestock Research' in de grijze balk onderaan). Wageningen Livestock Research verstrekt geen gedrukte exemplaren van rapporten.

\section{(C) 2020 Wageningen Livestock Research}

Postbus 338, 6700 AH Wageningen, T 03174839 53, E info.livestockresearch@wur.nl, www.wur.nl/livestock-research. Wageningen Livestock Research is onderdeel van Wageningen University \& Research.

Wageningen Livestock Research aanvaardt geen aansprakelijkheid voor eventuele schade voortvloeiend uit het gebruik van de resultaten van dit onderzoek of de toepassing van de adviezen.

Alle rechten voorbehouden. Niets uit deze uitgave mag worden vermenigvuldigd en/of openbaar gemaakt worden door middel van druk, fotokopie, microfilm of op welke wijze dan ook zonder voorafgaande toestemming van de uitgever of auteur.

Wageningen Livestock Research is NEN-EN-ISO 9001:2015 gecertificeerd.

Op al onze onderzoeksopdrachten zijn de Algemene Voorwaarden van de Animal Sciences Group van toepassing. Deze zijn gedeponeerd bij de Arrondissementsrechtbank Zwolle.

Wageningen Livestock Research Rapport 1264 


\section{Inhoud}

$\begin{array}{ll}\text { Woord vooraf } & 5\end{array}$

$\begin{array}{ll}\text { Samenvatting } & 7\end{array}$

1

$\begin{array}{lr}\text { Inleiding } & 9\end{array}$

2

$\begin{array}{ll}\text { Proefopzet } & 10\end{array}$

2.1 Materiaal en methode $\quad 10$

2.2 Substraten 11

2.3 Dieren en management 13

2.4 Rondeel systeem $\quad 14$

2.5 Video opnames en gedragsobservaties $\quad 15$

$\begin{array}{lll}2.6 & \text { Data analyse } & 15\end{array}$

3

$\begin{array}{ll}\text { Resultaten } & 16\end{array}$

3.1 Gemiddelden $\quad 16$

$\begin{array}{lll}3.2 & \text { Het totale aantal hennen in de substraten } & 17\end{array}$

3.3 Het aantal stofbadende hennen in de verschillende substraten gedurende de $\begin{array}{ll}\text { waarnemingstijd } & 19\end{array}$

3.4 Het percentage stofbadende hennen in de verschillende substraten gedurende $\begin{array}{ll}\text { waarnemingstijd } & 20\end{array}$

4 Discussie $\quad 23$

$\begin{array}{ll}\text { Literatuur } & 24\end{array}$

Bijlage 1 Totaal aantal hennen unit 1 en unit 2 per dag 25

Bijlage 2 Aantal stofbadende hennen per dag 29

Bijlage 3 Percentage stofbadende hennen per dag 33 



\section{Woord vooraf}

In de ontwikkeling van duurzamere en gezondere pluimveebedrijven is het van belang oplossingen te vinden die tegelijk voldoen aan een scala aan behoeften van mens en dier, en eisen op het gebied van het milieu. Dat gaat niet altijd vanzelf samen. Voor kippen belangrijk natuurlijk gedrag als foerageren en stofbaden leidt in de huidige scharrelsystemen tegelijk ook tot forse emissies van fijnstof.

De grootste bron van fijnstof uit pluimveestallen is de gedroogde mest, die in de stallucht terecht komt door actief gedrag van de dieren, zoals scharrelen, springen en stofbaden. De luchtkwaliteit in pluimveestallen is daardoor ongezond voor de mensen die er in werken, en vermoedelijk ook voor de dieren zelf. Via het ventilatiesysteem wordt dit fijnstof vervolgens naar buiten geblazen, wat lokale gezondheidsrisico's voor omwonenden oplevert. Traditionele kooisystemen hebben dit probleem in veel mindere mate, maar zijn maatschappelijk ongewenst vanwege de beperking van dierenwelzijn in dergelijke systemen.

Een andere manier is om dit probleem bij de bron aan te pakken. Door kippen niet meer in hun eigen mest te laten scharrelen en stofbaden, maar in een ander substraat, en de mest daar frequent uit te verwijderen. Die benadering is in ontwikkeling, en daarbij is het nodig dat we beter weten welke materialen geschikt zouden zijn als substraat. We weten dat de eisen die een kip stelt aan stofbadmateriaal anders (en kritischer) zijn dan de eisen aan scharrelmateriaal. Een brongerichte maatregel met een ander scharrelmateriaal kan er daarom toe leiden dat het substraat niet meer geschikt is voor stofbadgedrag. In zo'n geval is een aparte stofbadgelegenheid (al of niet in een apart gebied) een vereiste. We weten echter niet zo goed aan welke eisen een stofbadsubstraat moet voldoen, om geschikt en aantrekkelijk te zijn voor leghennen. In de wetenschappelijke literatuur is er verrassend weinig over bekend. En die kennis is natuurlijk wél nodig voor een goed ontwerp van een stofbadgebied. Dit rapport doet verslag van een eerste pilotstudie om die leemte in onze kennis op te vullen.

Het rapport komt voort uit het project 'Ontwerpen voor een gezondere pluimveehouderij' dat zich richt op het interactief ontwerpen en ontwikkelen van houderijsystemen en systeemonderdelen voor de pluimveehouderij met een focus op gelijktijdige verbetering van: 1) de risico's voor de gezondheid van omwonenden, 2) emissies van fijnstof, ammoniak en endotoxinen, 3) de diergezondheid en het dierenwelzijn, en 4) het stalklimaat.

Een van de onderdelen in dit project is ontwerpadvies bij en welzijnsonderzoek tijdens de praktijkproef op het proefbedrijf in Geel van een nieuw huisvestingssysteem voor leghennen van Vencomatic met de werknaam Code2+. In dat systeem wordt kippenmest niet meer als strooisel- en stofbadsubstraat aangeboden, maar dagelijks verwijderd. Om te voorzien in de scharrelbehoefte is er een speciaal ingestrooid gebied voor scharrelgedrag en een speciale ruimte voor stofbadgedrag.

Een ander onderdeel van dit project betreft de ontwikkeling van een reinigingstechniek om mest zeer frequent uit het scharrelgebied te verwijderen, zonder het (andere) scharrelsubstraat te hoeven verversen.

Voor beide onderdelen is kennis over (de kenmerken van) geschikte scharrel- en stofbadmaterialen van belang. In 2019 is er al een pilotstudie uitgevoerd om alternatieven voor de huidige strooiselmest als scharrelsubstraat te onderzoeken op waardering door leghennen om te foerageren (Neijenhuis et al., 2019). Deze studie vult dat aan met een indicatief antwoord op de vraag welk substraat is geschikt voor leghennen om in te stofbaden.

Dank aan de inzet van de onderzoekers, Marcella Merkelbach van Vencomatic en bovenal voor de gastvrijheid en behulpzaamheid van Frans Maas van het Rondeel in Wintelre.

Bram Bos (projectleider) en Ellen van Weeghel 


\section{Samenvatting}

Het in dit rapport beschreven pilot experiment is uitgevoerd om vast te stellen welk type substraat wordt gewaardeerd door leghennen om in te stofbaden. De leghennen kregen de keuze tussen gemalen tarwestro, fijne houtvezels, kokosgruis en turf. Van turf is bekend dat het voldoet als stofbadsubstraat en dit was als controle behandeling in de pilot opgenomen. Het betreft een eenvoudige pilot, met als doel om op een snelle manier een indruk te krijgen of 1 ) er stofbad gedrag wordt vertoond in de substraten, 2) de frequentie van stofbadgedrag in de alternatieve substraten vergelijkbaar is met die in turf, en 3 ) de alternatieve substraten verschillen in de mate waarin stofbadgedrag wordt vertoond.

Hiertoe zijn gedurende een week video opnames gemaakt van 12.00 tot 17.00 uur, waarbij van tweemaal twee opeenvolgende dagen de opnames zijn uitgelezen. De genoemde substraten zijn tegelijkertijd en naast elkaar in een vierkante opzet aangeboden in afzonderlijke bakken van $100 \mathrm{x}$ $200 \mathrm{~cm}$, met een opstaande rand van $20 \mathrm{~cm}$. Een laag van $15 \mathrm{~cm}$ substraat was aanwezig in de eerste twee dagen en 10 centimeter in de tweede serie van twee dagen. De bakken zijn aangeboden in de overdekte uitloop van 2 naast elkaar gelegen units van een Rondeelstal voor leghennen.

Aan de hand van 10 minuten intervallen zijn vier opnamedagen uitgelezen, waarbij het totaal aantal hennen aanwezig in de bakken en het aantal stofbadende hennen is gescoord, en waaruit het percentage stofbadende hennen van het totale aantal aanwezige hennen is berekend.

Uit de resultaten kwam naar voren dat het gemiddelde aantal aanwezig hennen en stofbadende hennen verschillend was voor de substraten. In het kokosgruis werden gemiddeld over de vier dagen $10.5 \pm 5.5$ hennen waargenomen, waarvan er respectievelijk 5.4 5.2 aan het stofbaden waren. Voor het tarwestro was dit $1.6 \pm 2.1$ respectievelijk $0.2 \pm 0.6$, turf $11.56 \pm 5.9$ respectievelijk $6.8 \pm 4.7$ en zaagsel $0.8 \pm 1.4$ respectievelijk $0.08 \pm 0.3$ voor het gemiddeld aantal aanwezige en stofbadende hennen. De hennen vertoonden dus een duidelijke voorkeur voor het turf en het kokosgruis om te stofbaden. In het gemalen tarwestro en zaagsel zaten sporadisch hennen te stofbaden. Het percentage stofbadende hennen verschilde niet tussen de substraten, de verschillen tussen substraten waren alleen zichtbaar in de absolute aantallen. Opvallend was dat er in het kokosgruis en turf geen duidelijk piek in het stofbaden viel waar te nemen, maar dat gedurende de gehele waarnemingstijd hennen aan het stofbaden waren. De derde waarnemingsdag was direct nadat de bakken waren bijgevuld en gemengd. De hennen vertoonden duidelijk meer belangstelling voor de substraten op deze dag dan op de andere drie dagen.

Uit de resultaten kan geconcludeerd worden dat hennen kokosgruis boven houtzaagsel en gemalen tarwestro prefereren en dat kokosgruis niet veel onderdoet voor turf, dat als controle-substraat was opgenomen. In hoeverre kokosgruis ook na langer gebruik aantrekkelijk blijft is een vraag voor verder onderzoek. 


\section{$1 \quad$ Inleiding}

In de pluimveehouderij zijn nieuwe huisvestingssystemen voor leghennen in ontwikkeling, waaronder bijvoorbeeld het Code $2+$ systeem. In dergelijke systemen wordt naast een foerageerplateau, specifiek bedoeld voor foerageergedrag, een separate stofbadgelegenheid aangeboden. Hiervoor is een specifiek soort substraat nodig dat enerzijds geschikt is voor de stofbad behoefte van de leghen en anderzijds past bij de eisen op gebied van milieu en fijnstofemissie.

Stofbaden is gedrag, dat in de eerste week van het leven wordt ontwikkeld (Hogan et al., 1991), waarbij substraat in de veren wordt gewerkt. In de literatuur worden verschillende redenen voor stofbaden genoemd, te weten: 1) stofbaden reguleert de hoeveelheid vet in het verenpak, 2) het verbetert de structuur van de veren, 3) ectoparasieten worden verwijderd uit het verenkleed (Vestergaard, 1982) en 4) stofbaden kan een functie hebben bij de thermoregulatie (Van Liere, 1991). Van Liere (1991) onderscheidt twee fasen in het stofbaden: de inschudfase en de zijlig- en zijwrijffase. De eerste fase, de voorbereidende fase, dient om het substraat in het verenpak te brengen. De kippen zitten hierbij met opgezette veren op het substraat en maken heftige krabbewegingen met de poten en heftige schudbewegingen met de vleugels. Ook wrijven ze de nek door het substraat (Van Liere et al., 1990). De tweede fase (de zijlig- en zijwrijffase) dient om het substraat zijn werking in het verenpak te laten verrichten. De kip ligt hierbij op een kant en strekt de poot aan de andere zijde waardoor de zij waar de kip op ligt over de bodem wrijft. Na afloop schudden de dieren met een krachtige schudbeweging van het gehele lichaam het substraat er weer uit (Van Liere, 1991). Het is bekend dat (zon)licht het stofbaden stimuleert (Duncan et al., 1998). Wanneer hennen continu beschikking hebben over substraat wordt stofbaden meestal tussen 11.00 en 16.00 uur waargenomen met een piek in het stofbaden tussen 12.00 en 13.00 uur (Vestergaard, 1982). De gemiddelde duur van het stofbad ligt tussen de 20 en 30 minuten (Van Liere et al., 1990). Ook als de hennen niet over substraat beschikken en het stofbaden dus geen effect heeft op het verenvet, voeren hennen dit gedrag uit. Als stofbaden verhinderd wordt, halen de hennen dit gedrag later in (Van Liere et al., 1990).

Leghennen hebben een aantal voorkeuren voor een geschikt substraat om te stofbaden: 1) het tussen de veren kunnen werken van kleine deeltjes om daarmee het verendek te kunnen verzorgen en te reinigen (Van Liere et al., 1990), 2) kleinere deeltjes of deeltjes die gemakkelijk uit elkaar vallen hebben de voorkeur (Van Liere et al., 1990; Moesta et al., 2008), 3) een laag vetgehalte van het substraat, in ieder geval <4\% lipide wordt geprefereerd (Scholz et al., 2011) en 4) een substraat laag van $20 \mathrm{~cm}$ leidt tot het beter inschudden van de kleine deeltjes in de veren dan een dunne laag substraat (Moesta et al., 2008). Een substraat als zand is in houderijsystemen met mechanisch bewegende onderdelen meestal ongewenst, vanwege de schurende werking. Van zand is echter meermaals aangetoond dat het goed aansluit en voldoet aan de stofbad behoefte van kippen (Van Liere et al., 1990; Shields et al., 2004). Naast zand is ook van turf aangetoond dat het voldoet aan de stofbad behoefte van de leghen (de Jong et al., 2007). Echter, als nadeel van turf worden wel de negatieve milieu impact en de kostprijs genoemd. Turf is dus geen goede keuze voor commercieel gebruik. Daarom wordt er gekeken naar een aantal alternatieve substraten die uit de literatuur, ervaring van onderzoekers of verwachting naar voren komen als geschikt alternatief. De volgende alternatieve substraten zijn gekozen: 1) gemalen tarwestro, 2) houtzaagsel, 3) kokosgruis en vergeleken met 4) turf (positieve controle).

Doel van de in dit rapport beschreven pilot is om vast te stellen of leghennen in de bovengenoemde aangeboden substraten gaan stofbaden. Het betreft een eenvoudige pilot om op een snelle manier aan te tonen 1) of er stofbad gedrag wordt vertoond in een substraat, 2) of de frequentie van stofbadgedrag in de alternatieve substraten vergelijkbaar is met die in turf, en 3) of de alternatieve substraten verschillen in de mate waarin stofbadgedrag wordt vertoond. 


\section{Proefopzet}

\subsection{Materiaal en methode}

De proef is uitgevoerd in het Rondeel in Wintelre waar 3600 hennen per unit aanwezig zijn. De vier bakken met verschillend substraat (gemalen tarwestro, houtzaagsel, kokosgruis en turf) zijn tegelijkertijd en naast elkaar in een vierkante opzet aangeboden (Foto 1 ). De bakken zijn aangeboden in de overdekte uitloop van 2 naast elkaar gelegen units van het Rondeel (Figuur 2.1).

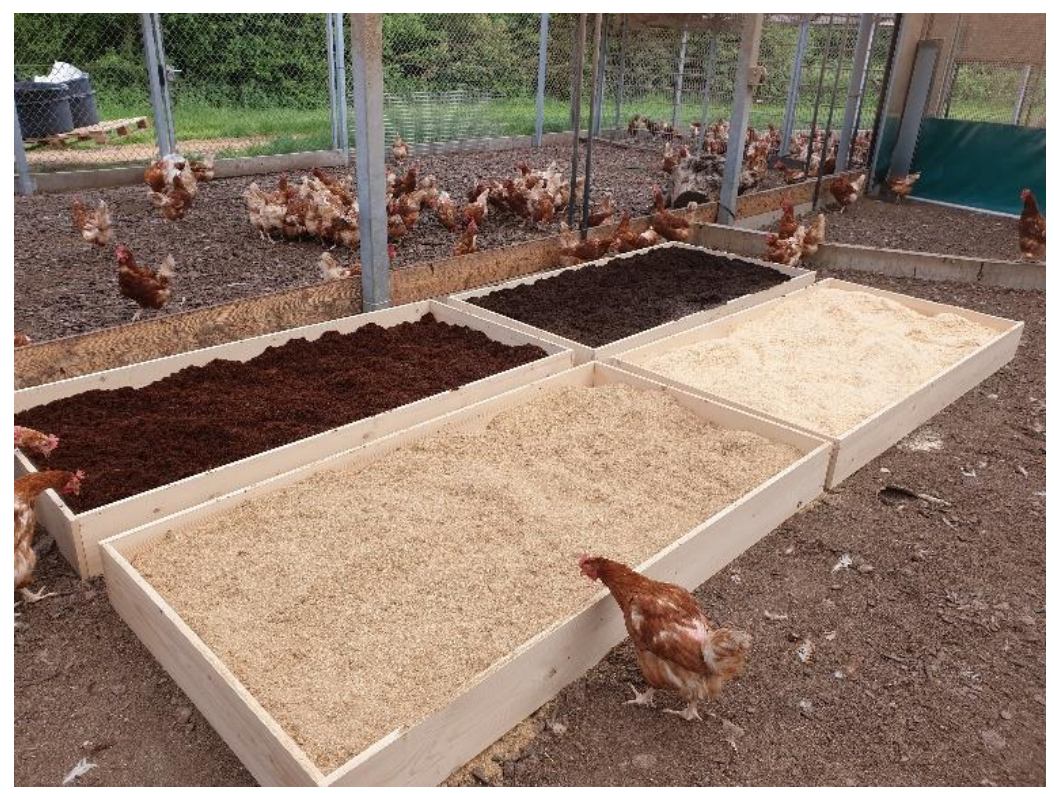

Foto 1 Opstelling van de substraatbakken in de overdekte buitenuitloop.

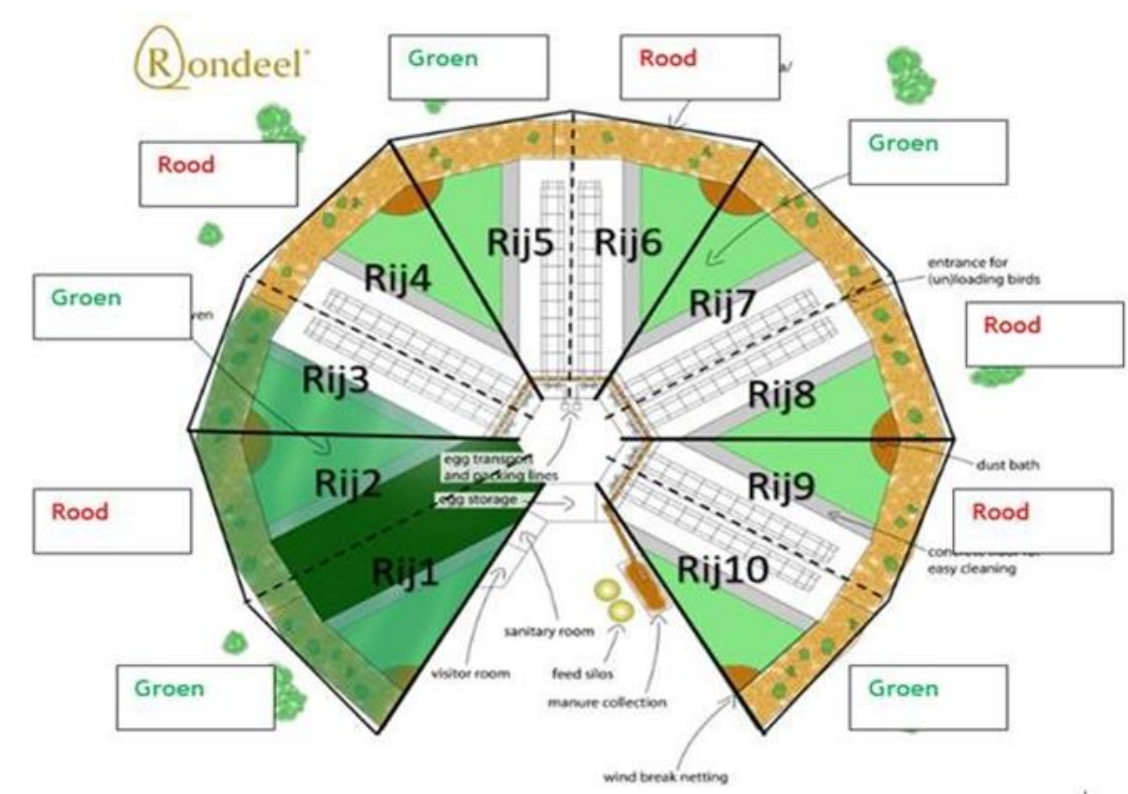

Figuur 2.1 Plattegrond van de proefstal. De bakken zijn aangebracht in rij 2 en 3 (twee separate units) in het lichtgroene deel (de overdekte buitenuitloop). 
De volgorde van substraat per unit was geloot en verschillend tussen beiden units om daarmee voor een eventuele locatievoorkeur van de hennen te corrigeren. De bakken hebben twee weken in de overdekte uitloop gestaan, waarbij gedurende tweemaal twee dagen met behulp van een camera boven de vier bakken video-opnames zijn gemaakt. De bakken waren gemaakt van vuren planken en hadden een formaat van $100 \times 200 \mathrm{~cm}$ met een opstaande rand van $20 \mathrm{~cm}$ waarin een laag van $15 \mathrm{~cm}$ substraat (eerste twee dagen) of 10 centimeter (tweede serie van twee dagen) was aangebracht (Foto 1). Vanwege de beperking in het oppervlak dat zichtbaar kan worden vastgelegd op de camera zijn de vier bakken met substraat met een tussenruimte van ongeveer 10 centimeter geplaatst (Foto 1).

Voorafgaande aan de eerste twee opnamen dagen (op 14 en 15 mei 2020) hebben de hennen drie dagen toegang tot de bakken gehad om te wennen aan de testsituatie en een mogelijk effect van de nieuwigheid en van het nog schone en verse substraat uit te kunnen sluiten. Vervolgens zijn er gedurende vier dagen opnames gemaakt. Er bleek echter dat de laatste twee dagen een camera was uitgevallen. Daarom zijn de substraten bijgevuld en gemengd en zijn er de volgende dag nogmaals gedurende 2 achtereenvolgende dagen opnames gemaakt (19 en 20 mei 2020). Wegens gebrek aan voldoende turf is nieuw turf verstrekt dat donkerder was en een andere structuur had dan het turf gebruikt op de eerste opnamedagen. Ook het kokosmateriaal was onvoldoende aanwezig om weer een laag van $15 \mathrm{~cm}$ aan te brengen en daarom werd een laag van circa $10 \mathrm{~cm}$ substraat aangebracht in alle bakken. In alle bakken is verder een deel van het substraat verwijderd en ververst, zodat de condities voor de substraten weer gelijk was gedurende de laatste twee opname dagen. De weersomstandigheden op donderdag 14 mei waren: helder, zonnig, $13^{\circ} \mathrm{C}$, en een windsnelheid tussen de 15 en $22 \mathrm{~km} / \mathrm{u}$. Vrijdag 15 mei: ging van helder naar bewolkt, $15^{\circ} \mathrm{C}$, en een windsnelheid tussen de 13 en $19 \mathrm{~km} / \mathrm{u}$. De weersomstandigheden gedurende de laatste twee opname dagen was enkele wolken, $23^{\circ} \mathrm{C}$, en een windsnelheid tussen de 11 en $17 \mathrm{~km} / \mathrm{u}$. Op woensdag 20 mei was het: enkele wolken, $22{ }^{\circ} \mathrm{C}$, en een windsnelheid tussen de 7 en $15 \mathrm{~km} / \mathrm{u}$.

\subsection{Substraten}

De gebruikte substraten staan hieronder beschreven, te weten: gemalen tarwestro, houtzaagsel, kokosgruis en turf.

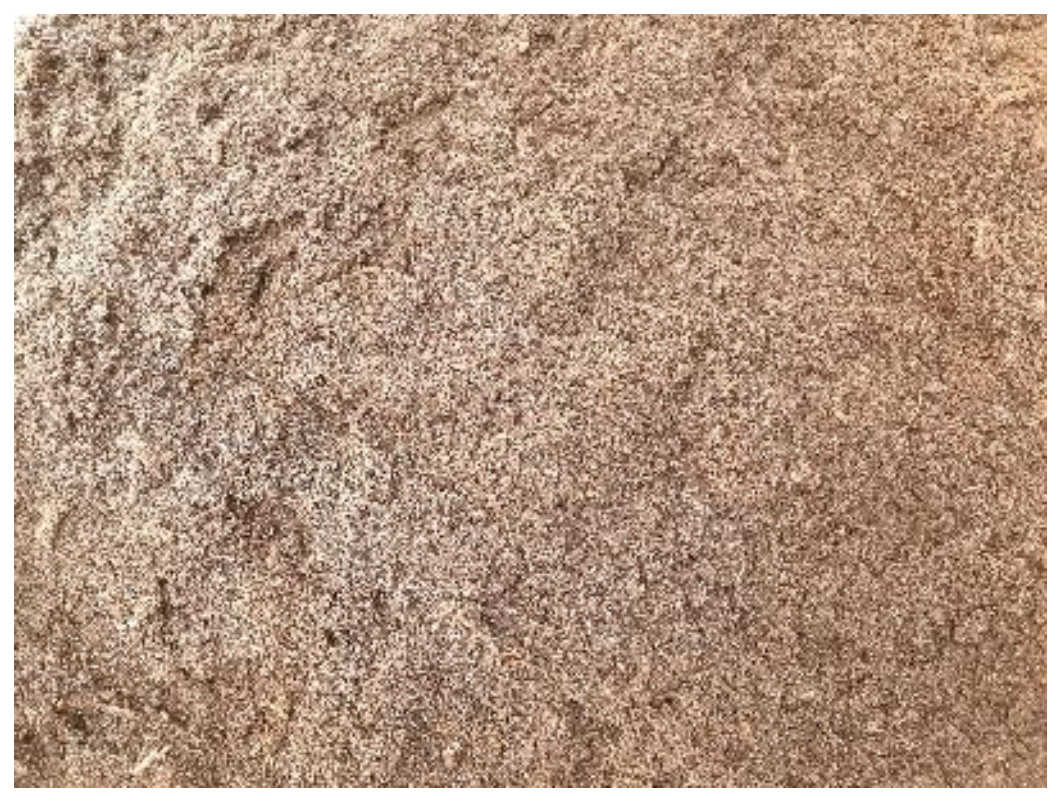

Foto 2 Gemalen tarwestro: het gemalen tarwestro was afkomstig van een bedrijf, dat verschillende soorten bodembedekking voor veehouderijbedrijven levert (De Hooifabriek - Nijssen Fourages B.V.). Het tarwestro wordt eerst gehakseld en vervolgens vermalen tot fijne deeltjes van 1-3 mm. Tijdens dit proces wordt het stro gezeefd en zoveel mogelijk stofvrij geblazen. Gemalen tarwestro is zeer fijn en heeft op het oog veel overeenkomsten met fijn houtzaagsel. Het gemalen stro heeft een bijna meelachtig textuur en kan meer vocht kan absorberen dan ongehakseld stro. 


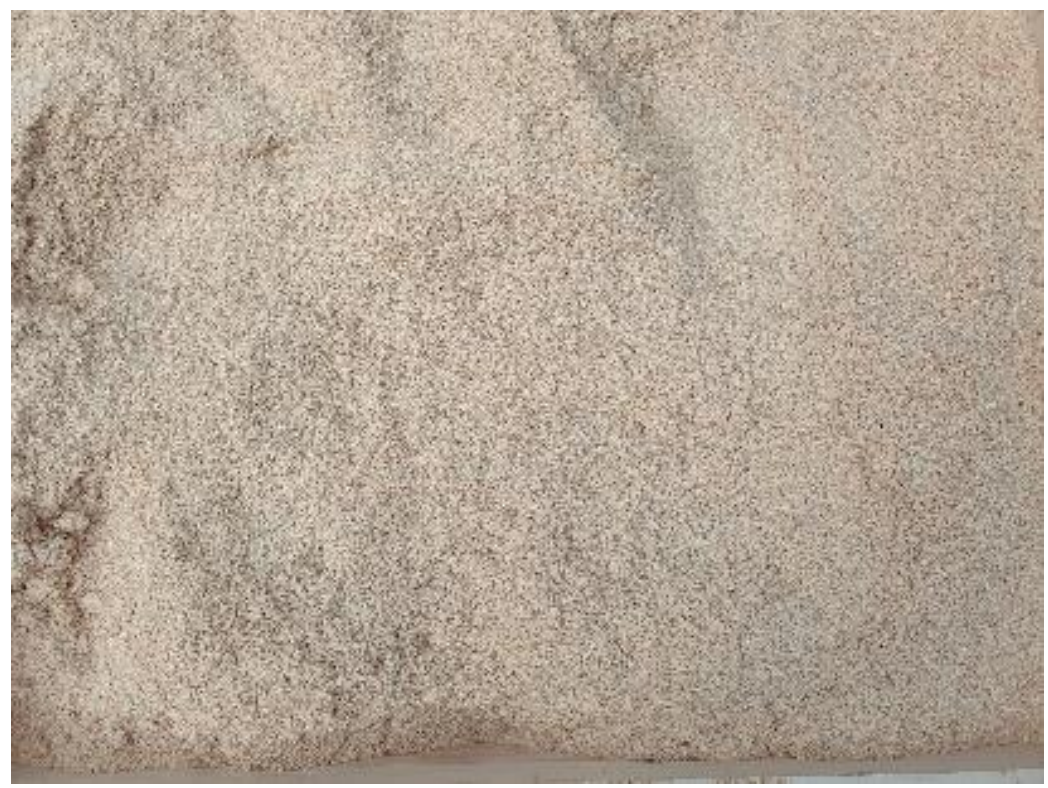

Foto 3 Houtvezel: Het fijne witte zaagselmeel was afkomstig van een bedrijf dat verschillende soorten bodembedekking voor veehouderijbedrijven levert (De Hooifabriek - Nijssen Fourages B.V.). Het zaagsel is een restproduct afkomstig van houtschaverijen. Het is het fijnste deel en bestaat uit fijne deeltjes van 1-3 mm. Het zaagsel wordt gezeefd en zoveel mogelijk stofvrij geblazen.

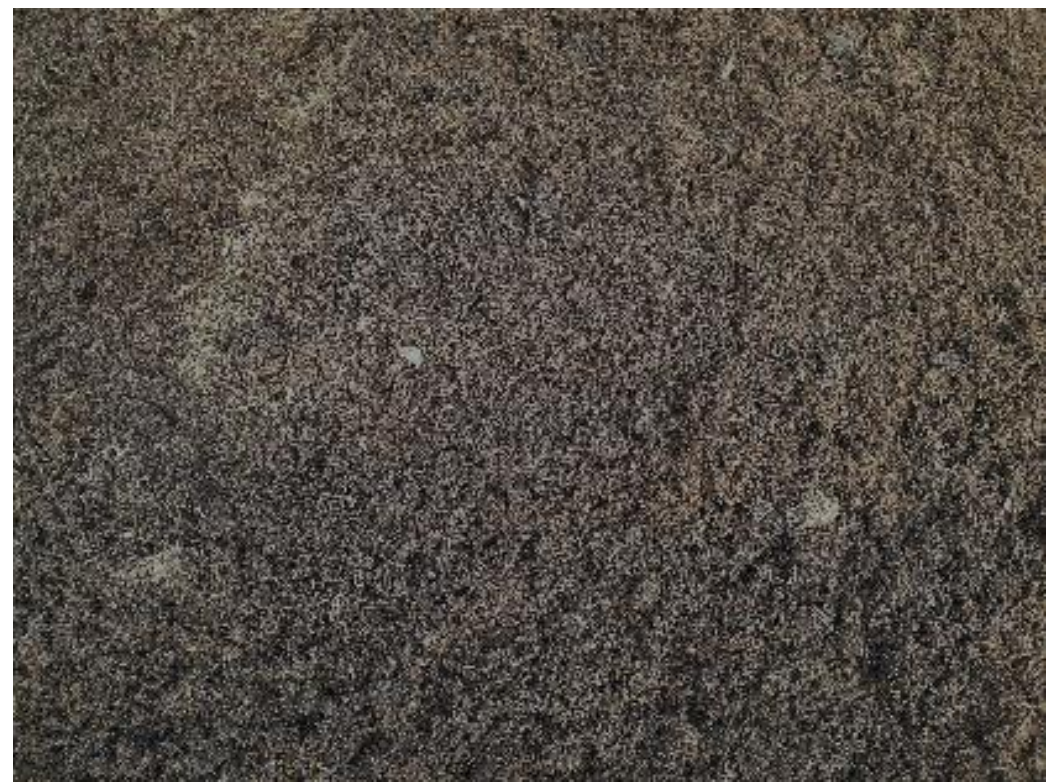

Foto 4 Kokosgruis: kokosgruis (het materiaal van de buitenkant van de kokosnoot) wordt in veel verschillende structuren aangeboden. Met name voor de tuin, aangevuld met voeding, als alternatief voor turf. Het wordt ook gebruikt voor terraria, en op kleinere schaal voor kleine hobbydieren, zoals konijnen en ook pluimvee. De structuur verschilt van lange vezels tot gruis waar het is vermalen en te vergelijken is met grond. In de proef is het fijne 'gruis' van het merk Trixie gebruikt (en niet de lange vezels), dat na een hittebehandeling voldoende veilig werd geacht om te gebruiken voor de proef. Het kokosgruis heeft een humus-achtige textuur en heeft op het oog veel overeenkomsten met turf. 


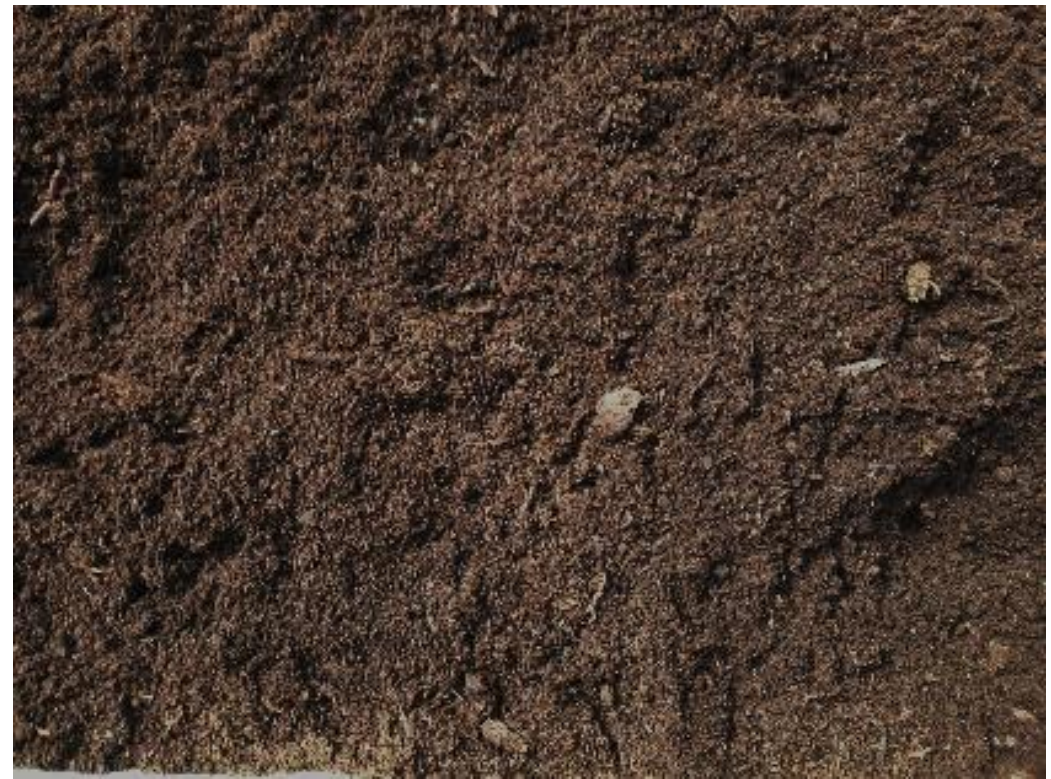

Foto 5 Turf: We hebben gebruik gemaakt van turf zoals aangeboden bij tuincentra. Voor de proef hebben we tuinturf afgenomen van de online leverancier 123natuurproducten.nl. Er is geen voorafgaand onderzoek gedaan aangezien turf is gebruikt in diverse proeven (o.a. (de Jong et al., 2007).

De volgorde van de vier substraten over de twee buitenuitlopen kwam tot stand op basis van loting en is weergegeven in Figuur 2.2.

Unit 1

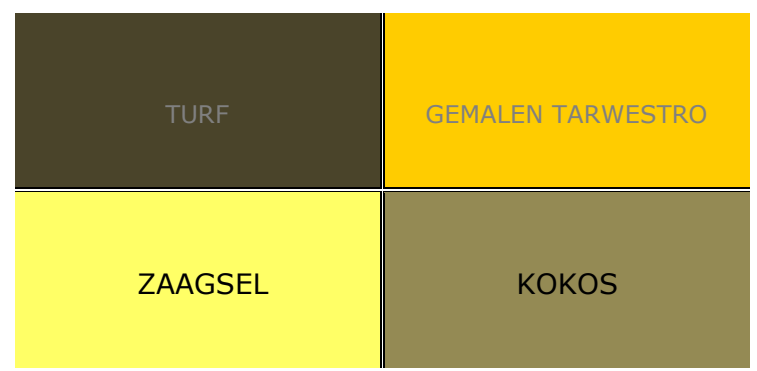

Unit 2

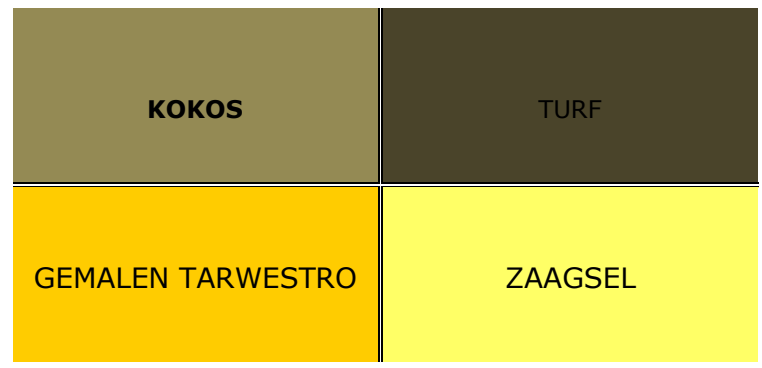

Figuur 2.2 Volgorde van de substraten aangeboden in de twee buitenuitlopen in respectievelijk unit 1 en 2.

\subsection{Dieren en management}

De leghennen waren van het merk Lohmann Brown Light en bij het begin van de proef 62 weken oud. $\mathrm{Bij}$ het begin van de proef waren er gemiddeld 3480 leghennen per unit. Het licht ging in de binnenruimte (buitengang en middengang) aan om 5:30 uur en uit om 21:20 uur gevolgd door 10 minuten dimperiode. Onder de Bolegg Terrace in de binnenruimte ging het licht om 21:15 uur uit en 
op het 1e niveau om 21:35 uur. Boven de Bolegg Terrace ging om 21.00 uur het licht op 90\%, om 21:30 uur 25 minuten op 10\% en was dan om 22:15 uur uit. De leghennen kregen om 6:30 uur toegang tot de overdekte buitenruimte en de bosrand, door het scherm omhoog te lieren. Om 22:15 uur ging het scherm weer dicht.

\section{$2.4 \quad$ Rondeel systeem}

Het Rondeel systeem is opgebouwd in een ringvorm, waarbij van binnen naar buiten de volgende onderdelen zijn te onderscheiden: 1) het binnen verblijf met Bolegg Terrace waarin voer en water worden aangeboden (zie Figuur 2.1). Vervolgens een overdekte buitenuitloop met oplierbare springtafels (foto 6). En als buitenste ring een niet overdekte buitenuitloop, de zogenaamde bosrand. De vier substraatbakken waren opgesteld in twee units van de overdekte buitenuitloop (Foto 1). In de overdekte buitenuitloop was de bodem tijdens de waarnemingen bedekt met een laag van met name gedroogde mest.
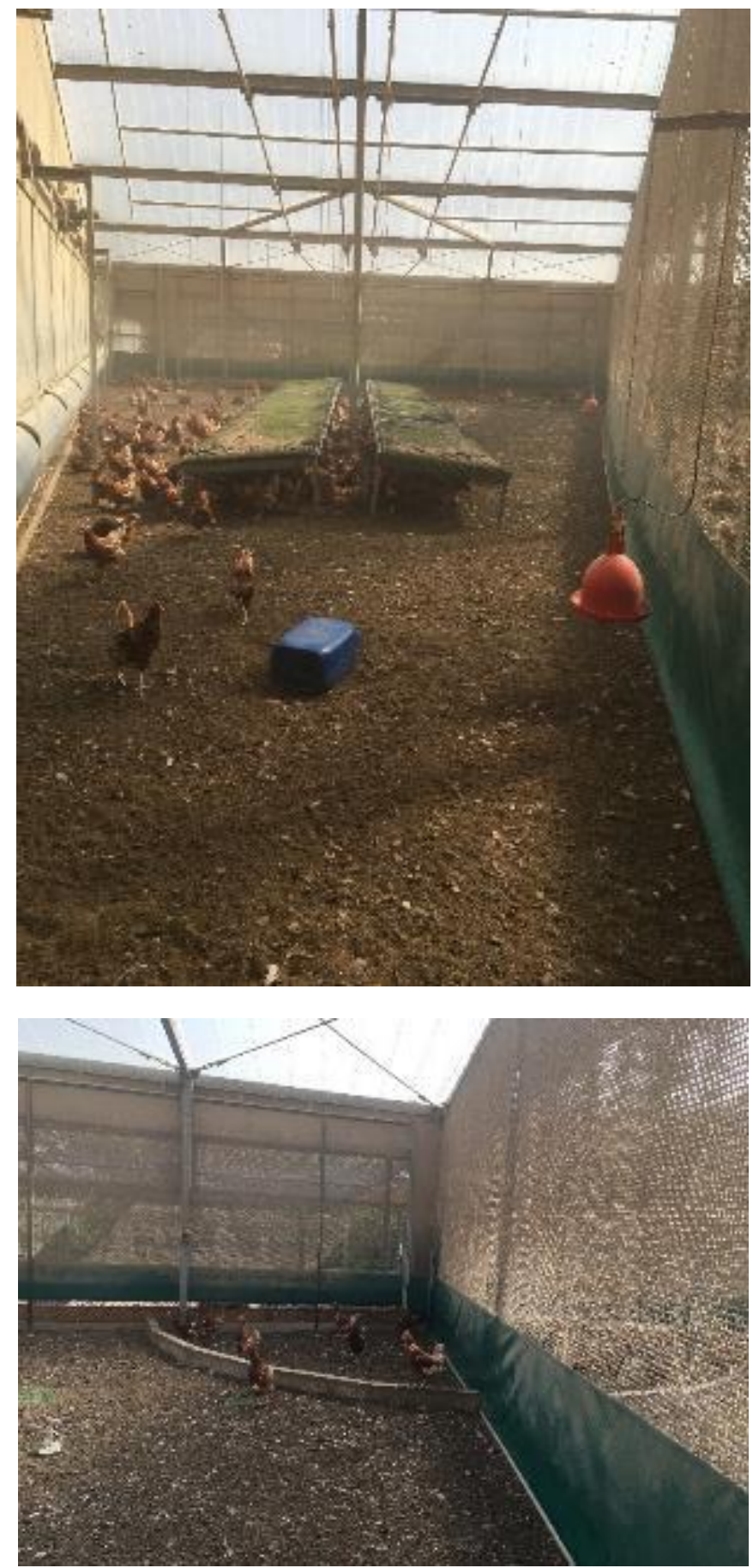


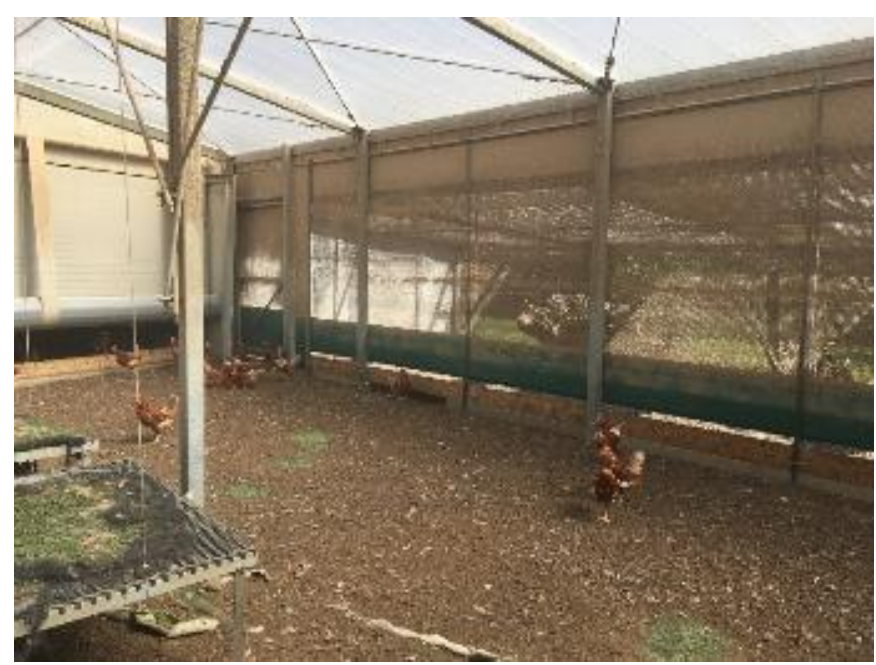

Foto 6, 7, 8 Foto's van de situatie in de overdekte buitenuitloop voordat de bakken waren geplaatst. De afgescheiden hoek die zichtbaar is in de overdekte uitloop, is in de separate stofbadruimte van het rondeel. Tijdens de waarnemingen was daar hetzelfde substraat aanwezig als in de rest van de overdekte uitloop.

\subsection{Video opnames en gedragsobservaties}

Gedurende tweemaal twee opeenvolgende dagen (14 en 15 mei 2020, en 19 en 20 mei 2020) zijn van 12.00 tot 17.00 uur video opnames gemaakt. Deze video opnames zijn door één persoon uitgelezen op de volgende wijze. Elke tien minuten werd het beeld vastgezet om het aantal hennen in de bakken te tellen en vervolgens werd het beeld op afspelen gezet om het aantal stofbadende hennen goed te kunnen onderscheiden van niet-stofbadende hennen. De buitenste hoeken van de onderste bakken waren niet volledig in beeld (minder dan $5 \%$ van het totale oppervlak) waardoor mogelijk te weinig hennen in deze bakken zijn geteld. Het aantal hennen dat daadwerkelijk in beeld gezien kon worden is geregistreerd. Een hen werd in de bak geteld wanneer zij met beide poten in de bak stond. Hennen die op de rand van de bakken zaten zijn niet meegeteld. Een hen werd als stofbadend geregistreerd wanneer zij een van de volgende bewegingen maakte: liggen zijwaarts, krabben, vleugels bewegen (inschudden), kop en nek tegen de grond, uitschudden, of wanneer substraat werd geobserveerd in de veren.

\subsection{Data analyse}

De video observaties zijn uitgewerkt en opgeslagen in een Excel bestand. Van elke dag is van 12.00 tot 17.00 uur per 10 minuten zowel het totaalaantal hennen aanwezig in de bakken als ook het aantal stofbadende hennen geregistreerd. Vervolgens zijn deze aantallen over de tijd grafisch weergegeven voor de vier afzonderlijke observatie dagen. Daarnaast is het gemiddeld aantal hennen, het aantal stofbadende hennen en het percentage van de hennen in de bakken die aan het stofbaden waren per dag en over de totale waarnemingstijd berekend. Omdat er slechts in 2 units is waargenomen is verdere statistische analyse niet zinvol $(n=2)$. Omdat stofbaden langer kan duren dan 10 minuten, zijn hennen mogelijk dubbel geteld. Door de waarnemingsmethode was het echter niet mogelijk om dubbeltellingen te voorkomen. Dat heeft echter geen effect op de relatieve vergelijking tussen de verschillende substraten. 


\section{Resultaten}

\subsection{Gemiddelden}

In Tabel 3.1 staan per dag de gemiddelde aantallen hennen, aantal stofbadende hennen en het percentage van de aanwezige hennen dat in de substraten aan het stofbaden is weergegeven. Omdat dag 3 de eerste dag na het bijvullen en mengen was, en de hennen duidelijk meer belangstelling toonden voor het substraat op deze dag dan op de andere drie dagen, is deze dag afzonderlijk weergegeven en zijn daarnaast de gemiddelden van dag 1, 2 en 4 opgenomen in de tabel. Uit deze tabel blijkt dat het gemalen tarwestro en houtvezel relatief weinig aantrekkelijk waren voor de hennen, zowel om in te verblijven (totale aantal hennen) als om in te stofbaden (aantal stofbadende hennen). De hennen vertoonden een duidelijke voorkeur voor kokosgruis en turf. De aantallen (stofbadende) hennen in het kokosgruis en de turf lagen dichtbij elkaar, en waren op de vierde dag zelfs hoger in het kokosgruis dan in de turf. In de bakken met kokosgruis en turf was de bezetting van hennen dusdanig hoog, dat de bakken op sommige tijdstippen geheel gevuld waren met hennen. Hierdoor was het totaalaantal hennen en het aantal stofbadende hennen moeilijk nauwkeuring vast te stellen, omdat hennen achter elkaar lagen en niet alle hennen zichtbaar waren. Op die momenten is een inschatting gemaakt van het totale aantal hennen en het aantal stofbadende hennen.

Het percentage stofbadende hennen van het totale aantal aanwezige hennen verschilde niet tussen de substraten, de verschillen tussen substraten waren alleen zichtbaar in de absolute aantallen.

Daarnaast werd opgemerkt dat stofbaden wel voorkwam in de minder favoriete substraten (zaagsel en tarwestro), maar dat het hier slechts om enkele hennen ging. 
Tabel 3.1 Gemiddelde aantallen (en s.d.) aanwezige en stofbadende hennen in de verschillende substraten.

\begin{tabular}{|c|c|c|c|c|c|c|c|}
\hline Dag & substraat & N totaal & $\begin{array}{l}\text { s.d N } \\
\text { totaal }\end{array}$ & N stofbad & $\begin{array}{l}\text { s.d. n } \\
\text { stofbad }\end{array}$ & $\%$ stofbad & $\begin{array}{l}\text { s.d. } \% \\
\text { stofbad }\end{array}$ \\
\hline \multirow[t]{4}{*}{1} & Kokos & 7.3 & 3.7 & 1.8 & 1.9 & 30.1 & 14.6 \\
\hline & Tarwestro & 1.3 & 1.5 & 0.2 & 0.5 & 58.3 & 25 \\
\hline & Turf & 10.7 & 5.6 & 4.6 & 3.7 & 43.3 & 18.1 \\
\hline & zaagsel & 0.4 & 0.7 & 0.03 & 0.2 & 41.7 & 11.8 \\
\hline \multirow[t]{4}{*}{2} & Kokos & 10.2 & 4.4 & 2.9 & 2.9 & 34.6 & 16.9 \\
\hline & Tarwestro & 2.8 & 2.9 & 0.3 & 0.6 & 29.8 & 22.8 \\
\hline & Turf & 14.4 & 3.8 & 7.7 & 2.8 & 54.1 & 15.4 \\
\hline & zaagsel & 1.8 & 2.0 & 0.1 & 0.5 & 53.3 & 32.1 \\
\hline \multirow[t]{4}{*}{$3^{*}$} & Kokos & 14.3 & 4.4 & 10.9 & 4.4 & 75.1 & 18 \\
\hline & Tarwestro & 1.0 & 1.6 & 0.2 & 0.6 & 67.5 & 30.1 \\
\hline & Turf & 14.2 & 6.1 & 11.5 & 4.8 & 81.6 & 11.5 \\
\hline & zaagsel & 0.4 & 0.7 & 0.1 & 0.4 & 79.2 & 25.0 \\
\hline \multirow[t]{4}{*}{4} & Kokos & 10.4 & 6.8 & 6.8 & 5.5 & 64.7 & 21.6 \\
\hline & Tarwestro & 1.1 & 1.6 & 0.2 & 0.6 & 74.4 & 32.3 \\
\hline & Turf & 7.3 & 5.0 & 3.8 & 3.3 & 55.2 & 21.6 \\
\hline & zaagsel & 0.6 & & 0.07 & & 66.7 & \\
\hline \multirow[t]{4}{*}{ Overall } & Kokos & 10.5 & 5.5 & 5.4 & 5.2 & 52.8 & 26.3 \\
\hline & Tarwestro & 1.6 & 2.1 & 0.2 & 0.6 & 50.3 & 31.4 \\
\hline & Turf & 11.56 & 5.9 & 6.8 & 4.7 & 58.8 & 21.8 \\
\hline & zaagsel & 0.8 & 1.4 & 0.08 & 0.3 & 61.9 & 28.1 \\
\hline \multirow[t]{5}{*}{$\begin{array}{l}\text { Overall } \\
\text { dag } 1,2 \\
\text { en } 4\end{array}$} & & & & & & & \\
\hline & Kokos & 9.3 & 5.3 & 3.8 & 4.3 & 44.0 & 23.8 \\
\hline & Tarwestro & 1.7 & 2.2 & 0.2 & 0.6 & 47.6 & 31.2 \\
\hline & Turf & 10.8 & 5.6 & 5.4 & 3.7 & 51.1 & 18.9 \\
\hline & zaagsel & 0.9 & 1.5 & 0.08 & 0.3 & 55.0 & 27.3 \\
\hline
\end{tabular}

* Dag 3 is de dag na het bijvullen en mengen van de substraten

\subsection{Het totale aantal hennen in de substraten}

In de onderstaande figuren zijn het aantal aanwezige hennen in de bakken gedurende de observatieperiode van 12.00 tot 17.00 uur weergegeven, gemiddeld voor dag 1,2 en 4 (Figuur 3.1) en op dag 3 (Figuur 3.2). Op dag 3 is de camera pas om 13:10 uur aangegaan, waardoor de periode van 12.00 tot 13.10 uur ontbreekt. De figuren voor de afzonderlijke dagen en units zijn opgenomen in Bijlage 1. Op dag 4 zitten er minder hennen in de bakken in unit 1 dan in unit 2. Rond 13.40-14.00 uur waren zelfs helemaal geen hennen in de bakken aanwezig. Tijdens de observatie zag je de hennen wegrennen. Mogelijk gebeurde er iets in deze unit wat de hennen heeft aangetrokken. 
gemiddelde aantal aanwezige hennen dag $1,2,4$ in unit 1 en 2

nokos - tarwestro -turf zaagsel

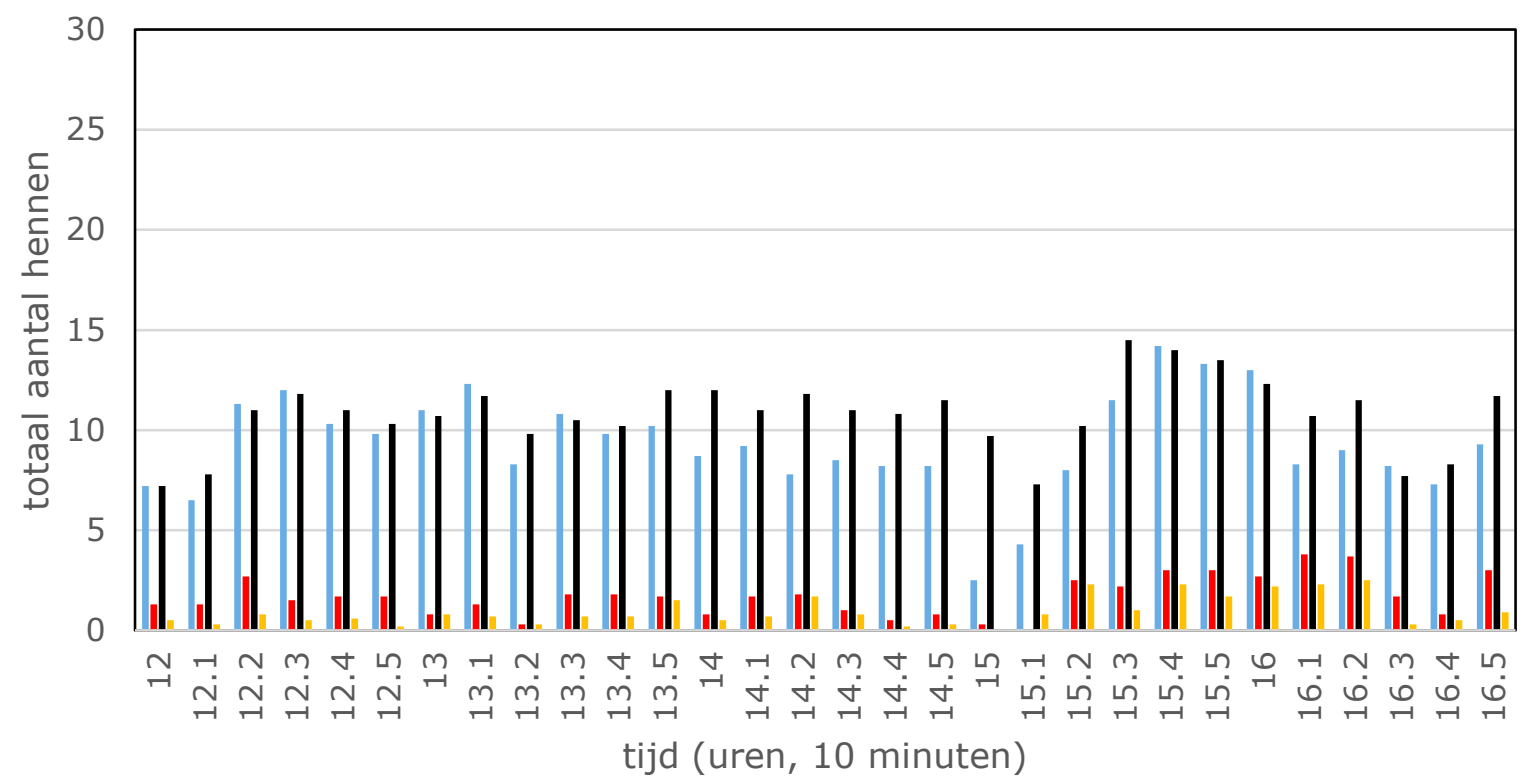

Figuur 3.1 Gemiddeld aantal aanwezige hennen in beide units in de verschillende substraten van 12.00 tot 17.00 uur (gemiddelde van dag 1,2 en 4 ).

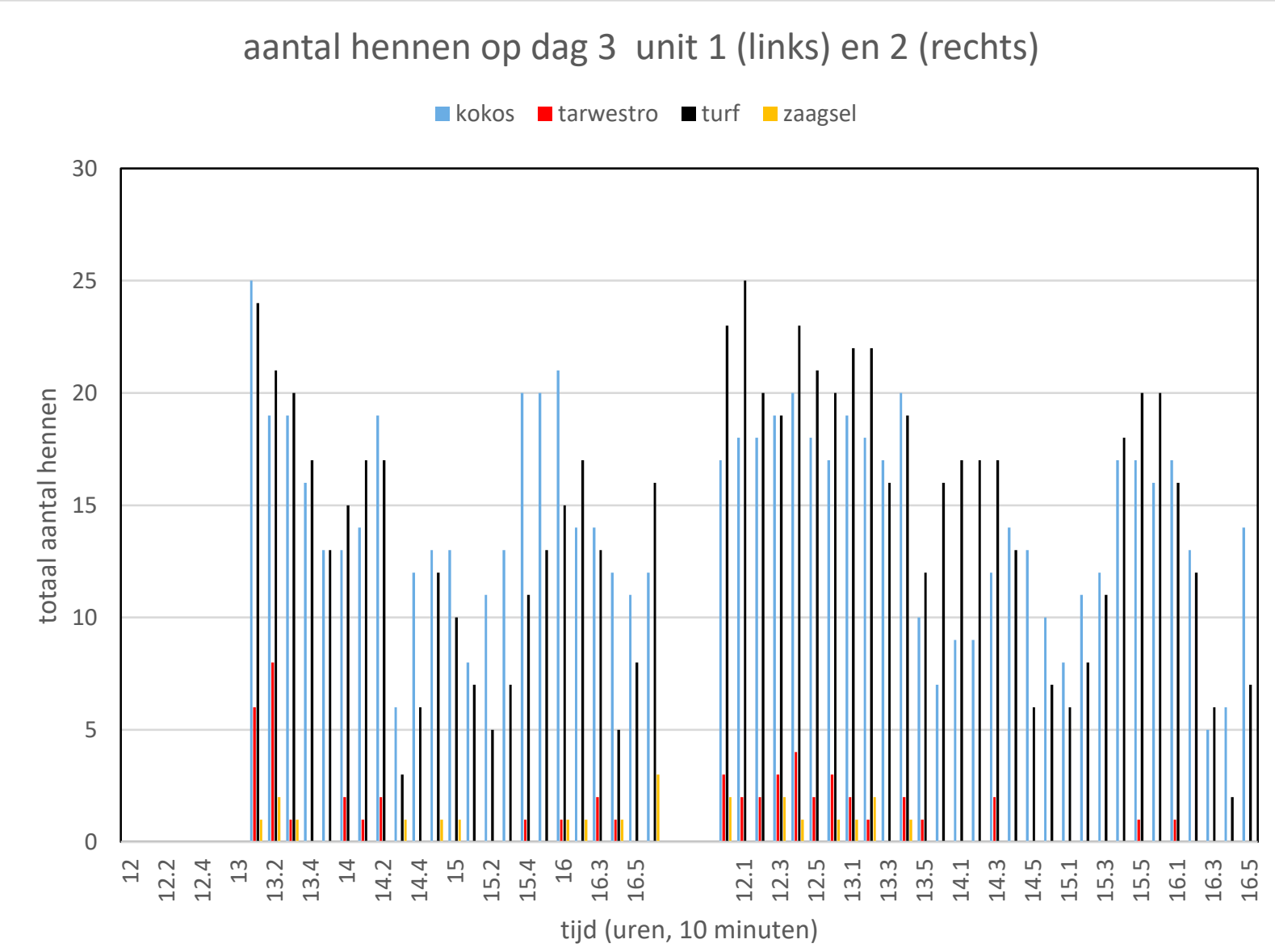

Figuur 3.2 Gemiddeld aantal aanwezige hennen in de verschillende substraten van 12.00-17.00 uur op dag 3 in unit 1 (links) en unit 2 (rechts). 
Uit de figuren 3.1 en 3.2 valt op dat in de bakken met turf en kokosgruis altijd hennen aanwezig zijn. Het gemalen tarwestro en het houtzaagsel daarentegen wordt slechts af en toe bezocht.

\subsection{Het aantal stofbadende hennen in de verschillende substraten gedurende de waarnemingstijd}

In de figuren 3.3 en 3.4 staat het aantal stofbadende hennen gemiddeld op dag 1,2, en 4 (Figuur 3.3) en dag 3 (Figuur 3.4) weergegeven in unit 1 en unit 2 gedurende de waarnemingstijd van 12.00-17.00 uur. De gegevens van de afzonderlijke dagen zijn weergegeven in Bijlage 2.

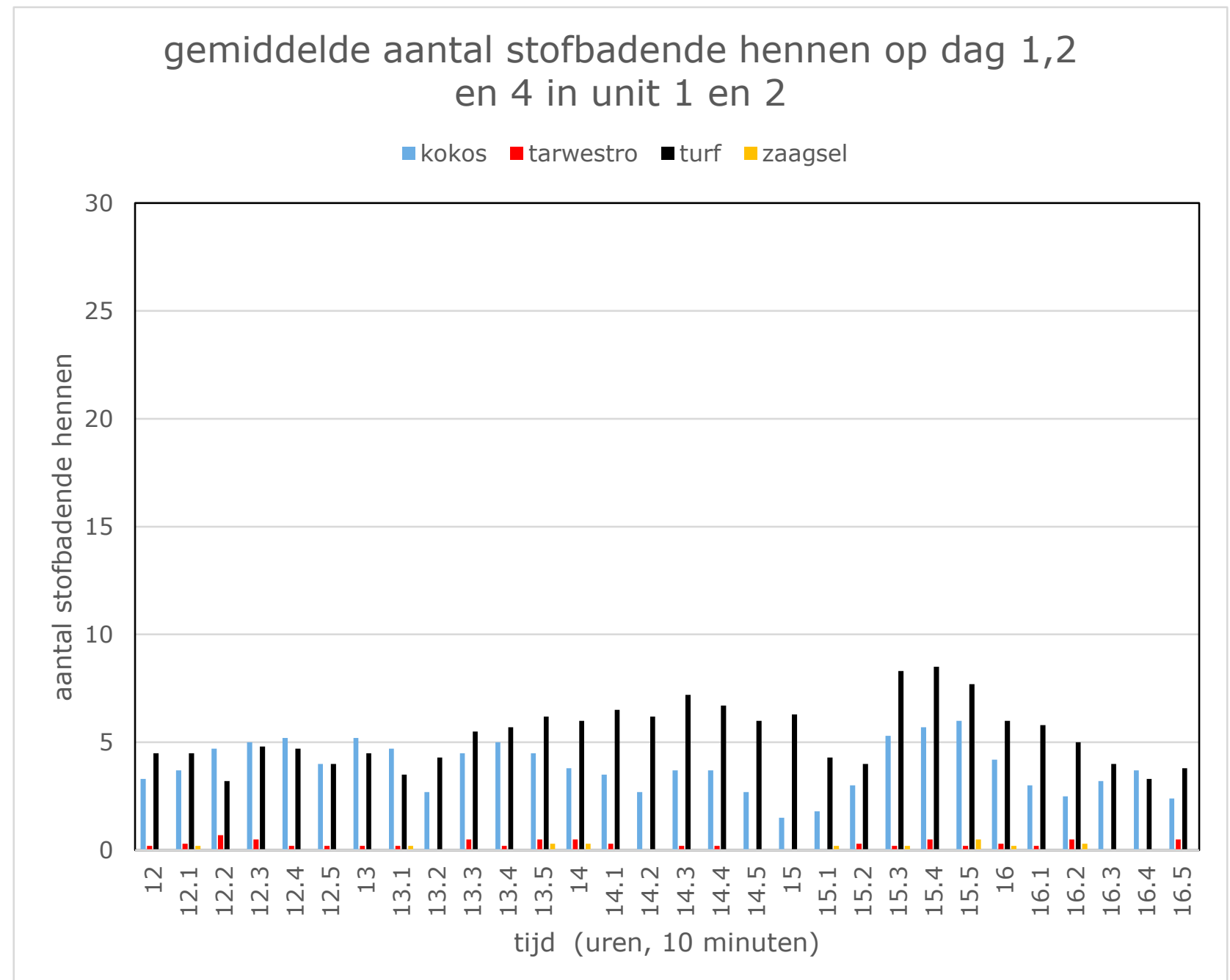

Figuur 3.3 Gemiddeld aantal stofbadende hennen in unit 1 en 2 in de verschillende substraten van 12.00-17.00 uur (gemiddelde dag 1,2 en 4). 


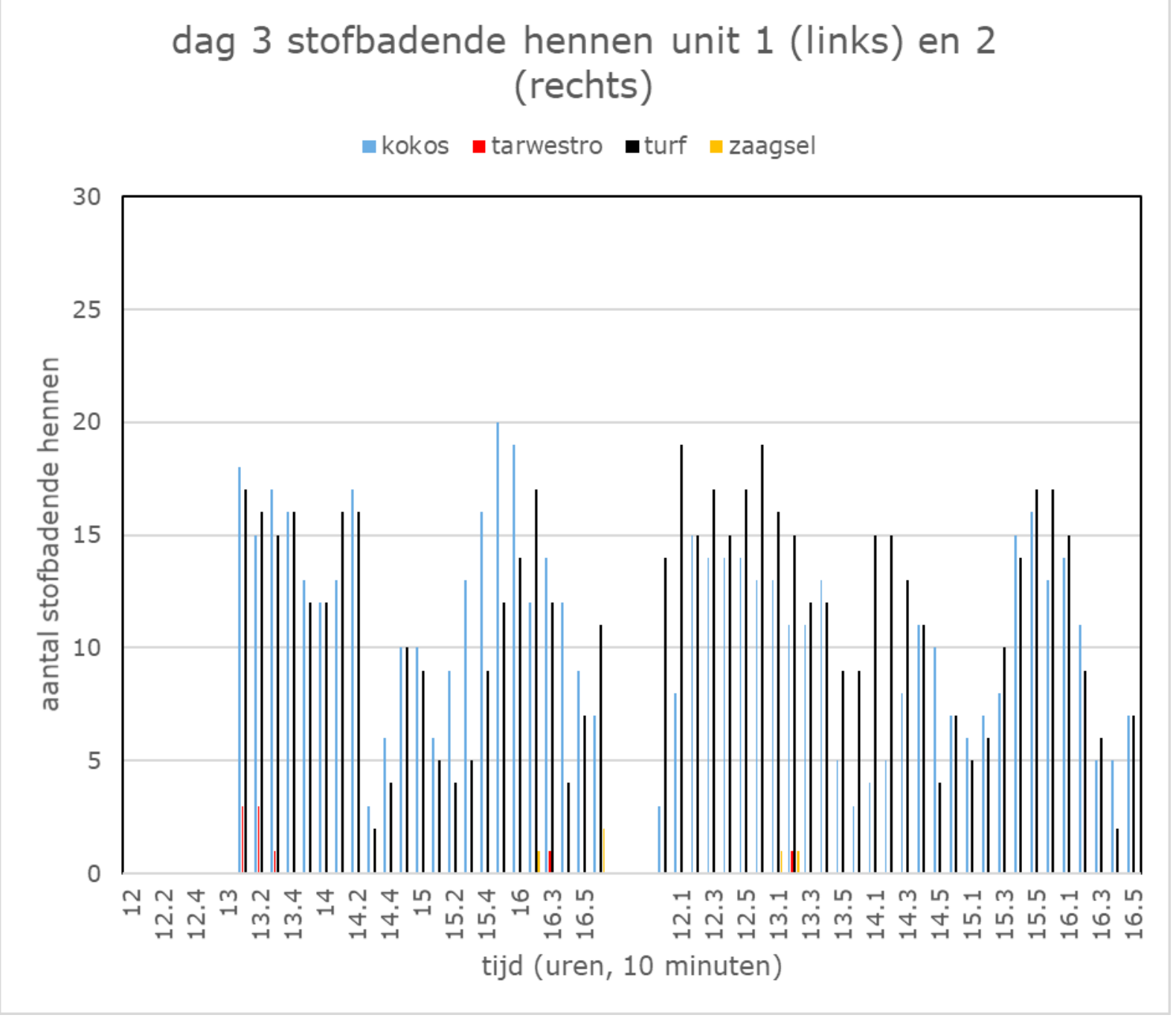

Figuur 3.4 Aantal stofbadende hennen in de verschillende substraten op dag 3 van 12.00-17.00 uur in unit 1 (links) en unit 2 (rechts).

Uit bovenstaande figuren komt hetzelfde beeld naar voren als in Tabel 1; de hennen vertonen een duidelijke voorkeur voor het turf en het kokosgruis om te stofbaden. In het gemalen tarwestro en zaagsel zitten sporadisch hennen te stofbaden. Opvallend is verder dat er in het kokosgruis en turf geen duidelijk piek in het stofbaden valt waar te nemen, maar dat gedurende de gehele waarnemingstijd hennen aan het stofbaden zijn. Uit de figuren in Bijlage 2 valt op dat op dag 4 in unit 1 minder stofbaden wordt gezien dan in unit 2. Mogelijk hangt dit samen met een gebeurtenis in deze unit; er werden ook minder hennen in de bakken gezien.

\subsection{Het percentage stofbadende hennen in de verschillende substraten gedurende waarnemingstijd}

In de figuren 3.5 en 3.6 is het percentage dieren dat aan het stofbaden is ten opzichte van het totaal aantal aanwezige hennen in de verschillende substraten weergegeven. In Figuur 3.5 staat het gemiddelde van dag 1, 2 en 4 in unit 1 en 2 . De afzonderlijke dagen staan weergegeven in Bijlage 3. Figuur 3.6 geeft het percentage stofbadende hennen op dag 3 weer van 12.00-17.00 uur in unit 1 en unit 2. 


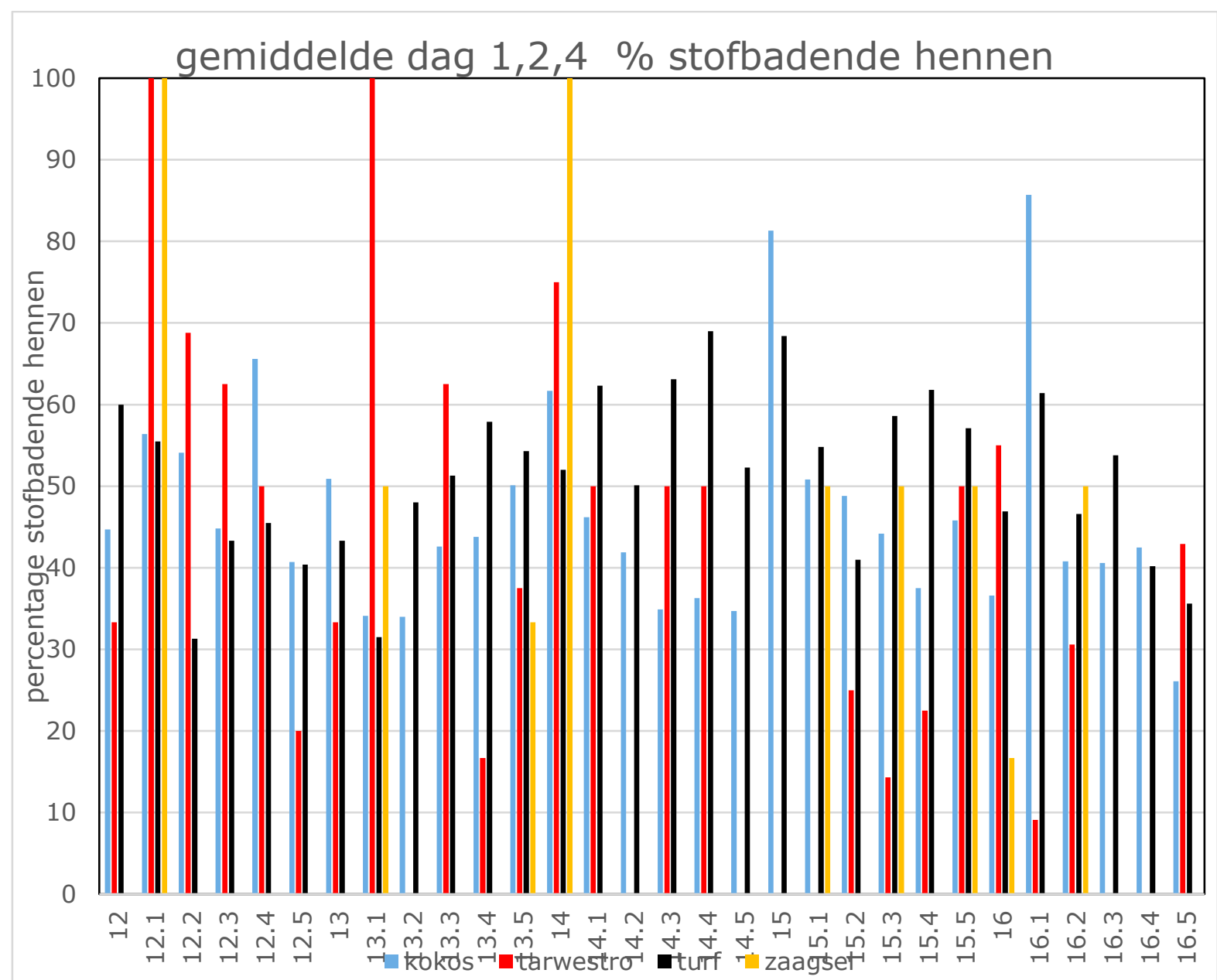

Figuur 3.5 Percentage stofbadende hennen in de verschillende substraten gedurende de waarnemingstijd van 12.00-17.00 uur (gemiddelde op dag 1, 2 en 4 in unit 1 en 2). 


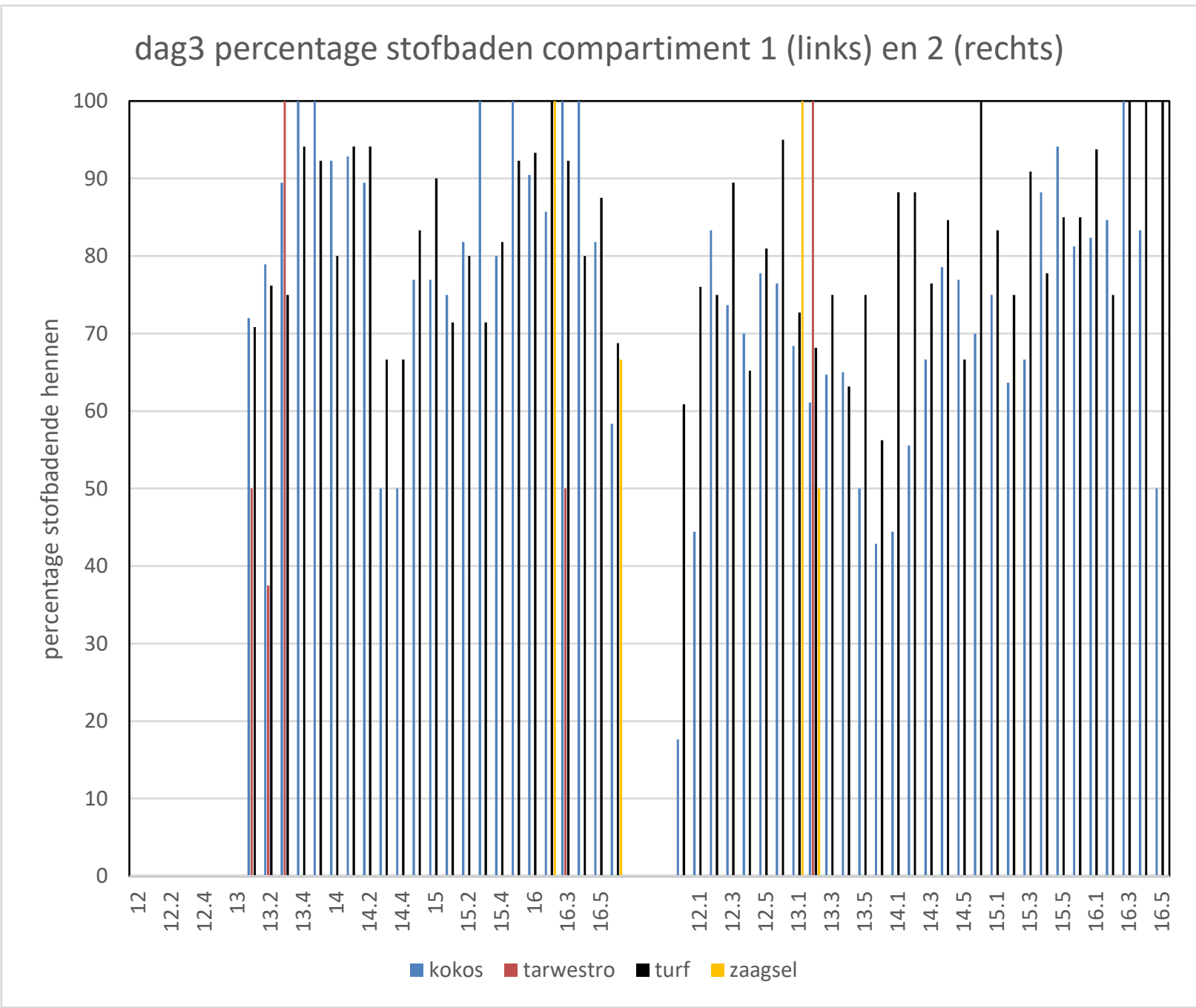

Figuur 3.6 Percentage stofbadende hennen in de verschillende substraten gedurende de waarnemingstijd van 12.00-17.00 uur op dag 3 in unit 1 (links) en unit 2 (rechts).

Uit de figuur 3.5 blijkt dat in het gemalen tarwestro en houtvezel de enkele hen die aanwezig is, aan het stofbaden is waardoor het percentage stofbadende hennen $100 \%$ is. In het kokosgruis en het turf is respectievelijk tussen de 30 en $80 \%$ (kokosgruis) en 30 en $70 \%$ (turf) van de aanwezige hennen aan het stofbaden. Naast het stofbaden werd in alle substraten ook scharrelgedrag waargenomen. Op dag 3 ligt het percentage stofbadende hennen in de turf en het kokosgruis hoger dan op de overige dagen. 


\section{$4 \quad$ Discussie}

Doel van de in dit rapport beschreven pilot was om na te gaan of hennen in de aangeboden substraten willen stofbaden en met welke frequentie, waarbij het turf als controle substraat was opgenomen omdat uit de literatuur bekend is dat dit een geprefereerd stofbadsubstraat is (de Jong et al., 2007). Uit de resultaten blijkt dat de hennen voornamelijk in het turf en kokosgruis stofbaden. Het gemalen tarwestro en houtvezel zijn duidelijk minder aantrekkelijk voor de hennen. Er werd slechts een enkele keer een stofbadende hen in waargenomen. Ook het aantal hennen dat in de substraten is geobserveerd verschilt duidelijk tussen de substraten. Ook hier geldt dat turf en kokosgruis de voorkeur hebben boven gemalen tarwestro en houtzaagsel. De hennen die niet aan het stofbaden waren, waren veelal aan het scharrelen.

Stofbaden is een gedrag dat veelal rond het middag uur wordt gezien (Vestergaard et al., 1990). Opvallend is dat er geen duidelijke piek in het stofbaden werd geobserveerd rond het middaguur, wat aanvankelijk wel werd verwacht. Het turf en kokosgruis werden gemiddeld genomen goed bezocht. Mogelijk is de beschikbare ruimte om te stofbaden beperkend geweest, waardoor de hennen hun stofbadgedrag uitstelden totdat er weer ruimte was, waardoor geen duidelijke piek optrad. Met name op dag 3, de dag nadat de substraten waren aangevuld en gemengd, bleken het turf en kokosgruis zeer aantrekkelijk en werd een hoog aantal stofbadende hennen in de bakken gezien. De vraag rijst in hoeverre de substraten langdurig aantrekkelijk blijven, zeker wanneer deze vervuild raken door mest. Hiervoor is het noodzakelijk om de observaties na enkele weken te herhalen.

Over de frequentie van stofbaden kunnen aan de hand van de gevolgde waarnemingsmethode geen duidelijke uitspraken worden gedaan. Stofbaden is een gedrag dat gekenmerkt wordt door een aantal fasen (inschudden, inwerken, uitschudden) waarbij de maximale duur rond 30 minuten ligt (Van Liere, 1991). Doordat er eenmaal per 10 minuten is gescoord hoeveel hennen aan het stofbaden waren, is het zeer waarschijnlijk dat er dubbeltellingen zijn opgetreden. Dus hoeveel hennen een stofbad hebben genomen tijdens de observaties is niet duidelijk. Hiervoor dienen hennen individueel gevolgd te worden. Ook over de kwaliteit van het stofbaden (dat wil zeggen, of alle elementen van het stofbadgedrag worden uitgevoerd (Van Liere, 1991)) kunnen geen uitspraken worden gedaan. De video opnamen waren niet geschikt om de verschillende fasen van het stofbad per hen goed te kunnen registreren.

Hoewel aan de hand van de gevolgde methodiek een groot aantal vragen open blijven, kan wel worden geconcludeerd dat hennen kokosgruis boven houtzaagsel en gemalen tarwestro prefereren en dat kokosgruis niet veel onderdoet voor turf, dat als controle substraat was opgenomen. In hoeverre kokosgruis ook na langer gebruik aantrekkelijk blijft is een vraag voor verder onderzoek. 


\section{Literatuur}

De Jong, I.C., Wolthuis-Fillerup, M., van Reenen, C.G., 2007. Strength of preference for dustbathing and foraging substrates in laying hens. Applied Animal Behaviour Science 104, 24-36.

Duncan, I.J.H., Widowski, T.M., Malleau, A.E., Lindberg, A.C., Petherick, J.C., 1998. External factors and causation of dustbathing in domestic hens. Behav. Processes 43, 219-228.

Hogan, J.A., Honrado, G.I., Vestergaard, K., 1991. Development of a Behavior System - Dustbathing in the Burmese Red Junglefowl (Gallus-Gallus-Spadiceus) .2. Internal Factors. J. Comp. Psychol. 105, 269273.

Moesta, A., Knierim, U., Briese, A., Hartung, J., 2008. The effect of litter condition and depth on the suitability of wood shavings for dustbathing behaviour. Applied Animal Behaviour Science 115, 160170.

Neijenhuis, F., van Wijhe-Kiezebrink, M., \& de Jong, I., 2019. Substraat voorkeur voor foerageergedrag leghennen : pilotstudie. Wageningen Livestock Research rapport; No. 1193. Wageningen, Wageningen Livestock Research. https://doi.org/10.18174/499912.

Scholz, B., Kjaer, J.B., Urselmans, S., Schrader, L., 2011. Litter lipid content affects dustbathing behavior in laying hens. Poultry Science 90, 2433-2439.

Shields, S.J., Garner, J.P., Mench, J., 2004. Dustbathing by broiler chickens: a comparison of preference for four different substrates. Appl. Anim. Behav. Sci. in press.

Van Liere, D.W., 1991. Function and organization of dustbathing in laying hens, Proefschrift Landbouwuniversiteit Wageningen, Wageningen.

Van Liere, D.W., Kooijman, J., Wiepkema, P.R., 1990. Dustbathing behaviour of laying hens as related to quality of dustbathing material. Appl. Anim. Behav. Sci. 26, 127-141.

Vestergaard, K.S., 1982. Dust-bathing in the domestic fowl - diurnal rhythm and dust deprivation. Appl. Anim. Ethol. 8, 487-495.

Vestergaard, K.S., Hogan, J.A., Kruijt, J.P., 1990. The development of a behavior system: dustbathing in the burmese red junglefowl 1 . The influence of the rearing environment on the organization of dustbathing. Behaviour 112, 99-116. 
Bijlage 1 Totaal aantal hennen unit 1 en unit 2 per dag

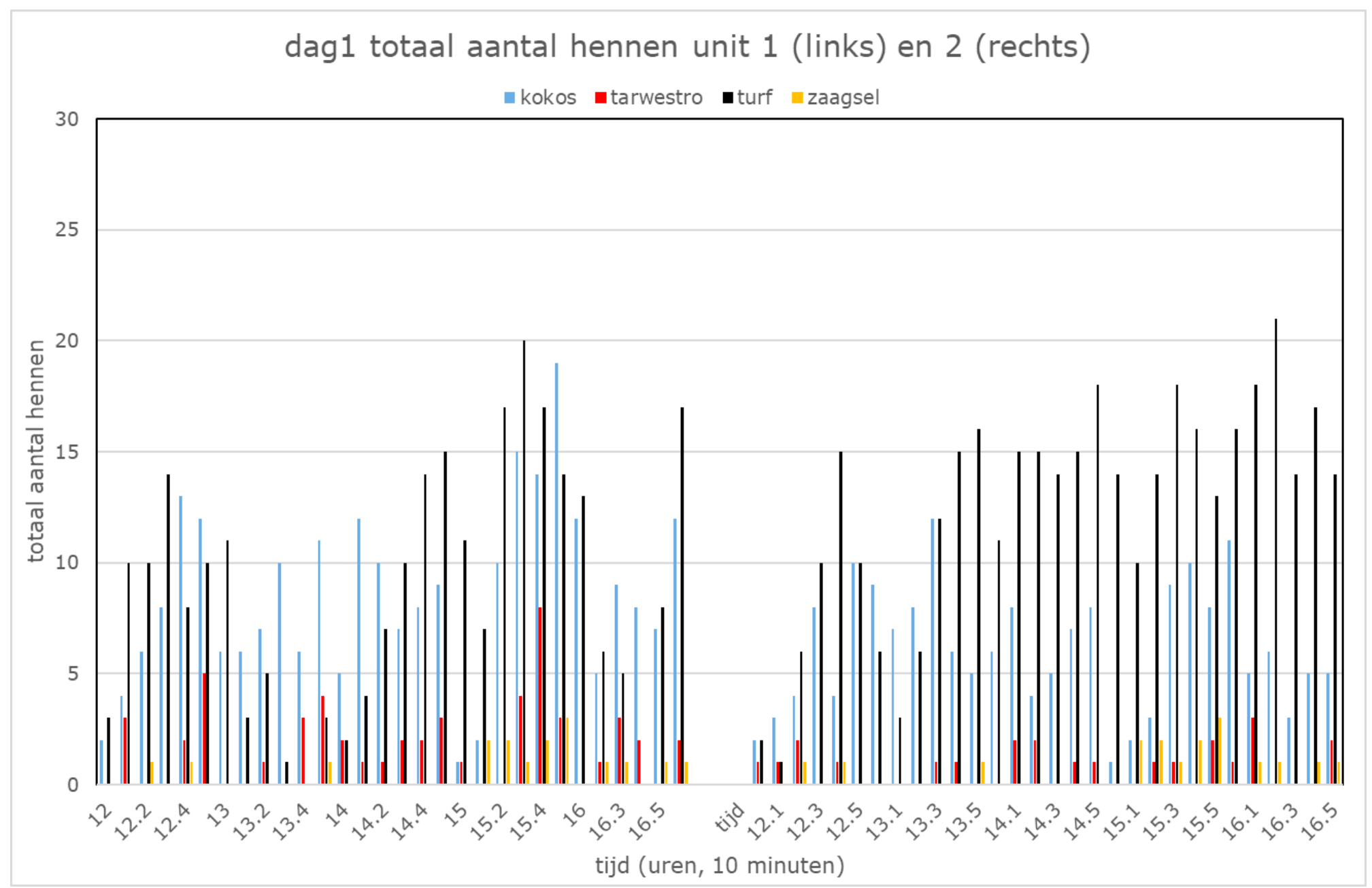

Figuur 1 Totaal aantal aanwezige hennen in de bakken met de verschillende substraten op dag 1 in unit 1 (links) en 2 (rechts). 
dag2 totaal aantal hennen unit 1 (links) en 2 (rechts)

-kokos - atarwestro -turf $\backsim$ zaagsel

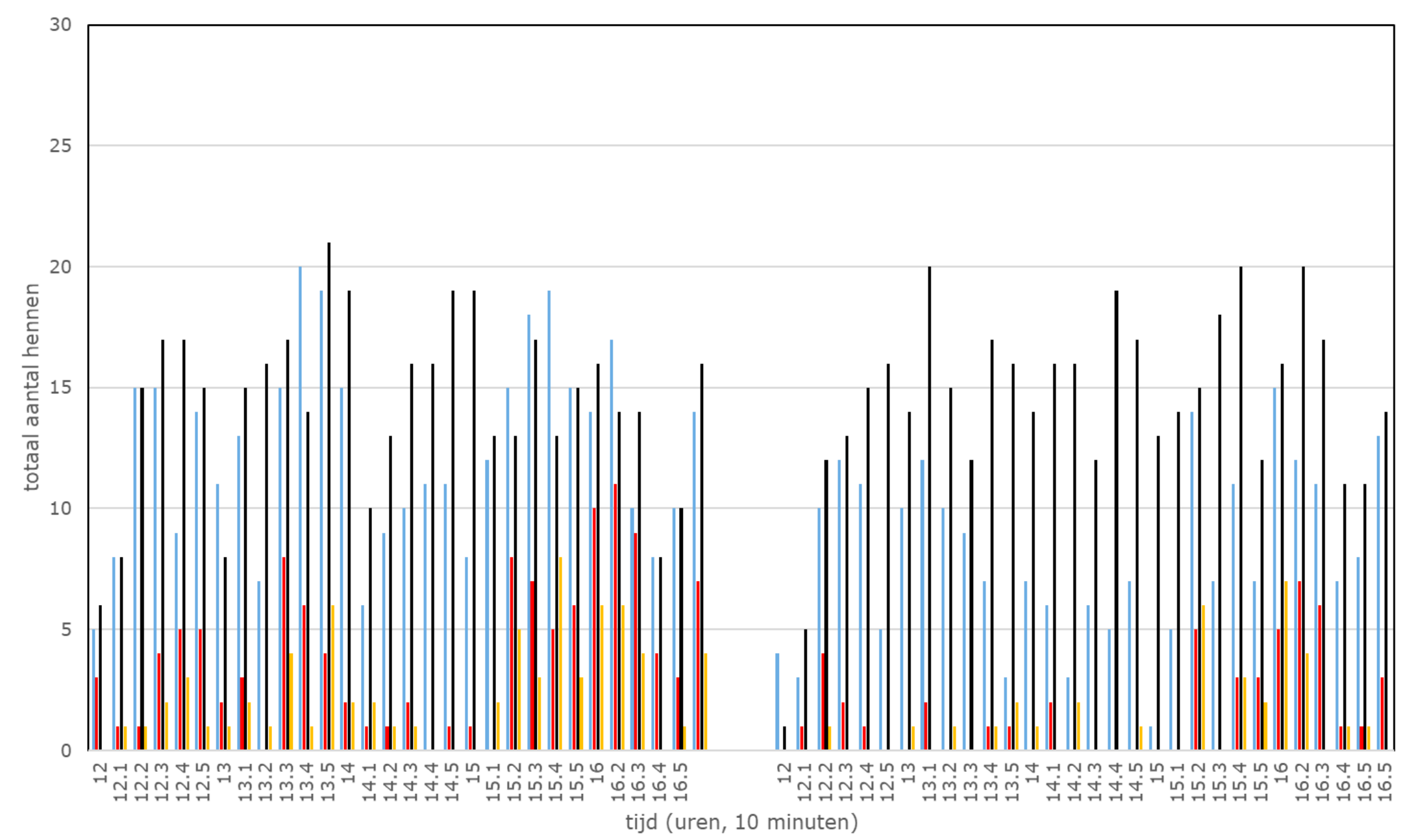

Figuur 2 Totaal aantal aanwezige hennen in de bakken met de verschillende substraten op dag 2 in unit 1 (links) en 2 (rechts). 


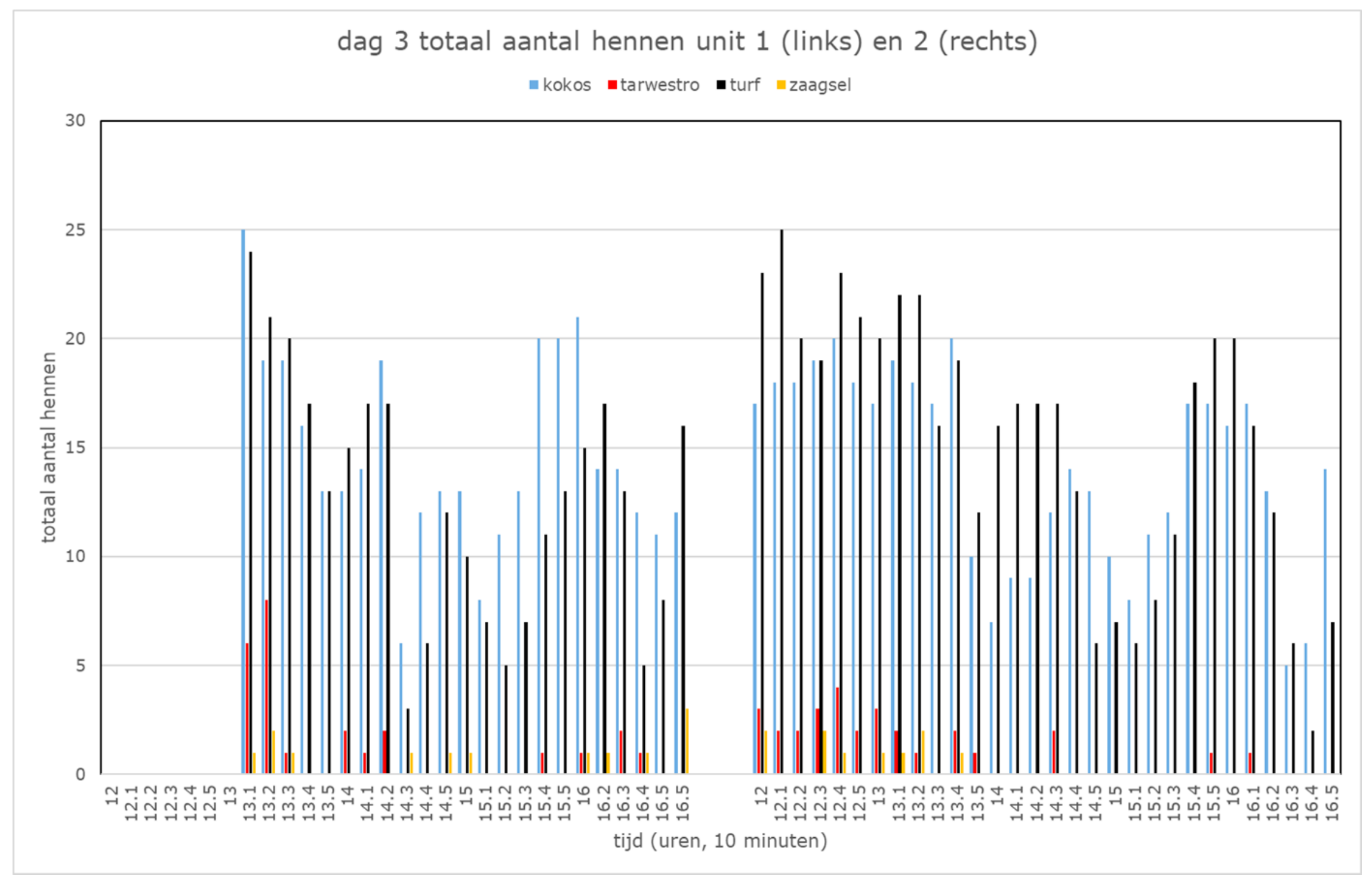

Figuur 3 Totaal aantal aanwezige hennen in de bakken met de verschillende substraten op dag 3 in unit 1 (links) en 2 (rechts). 


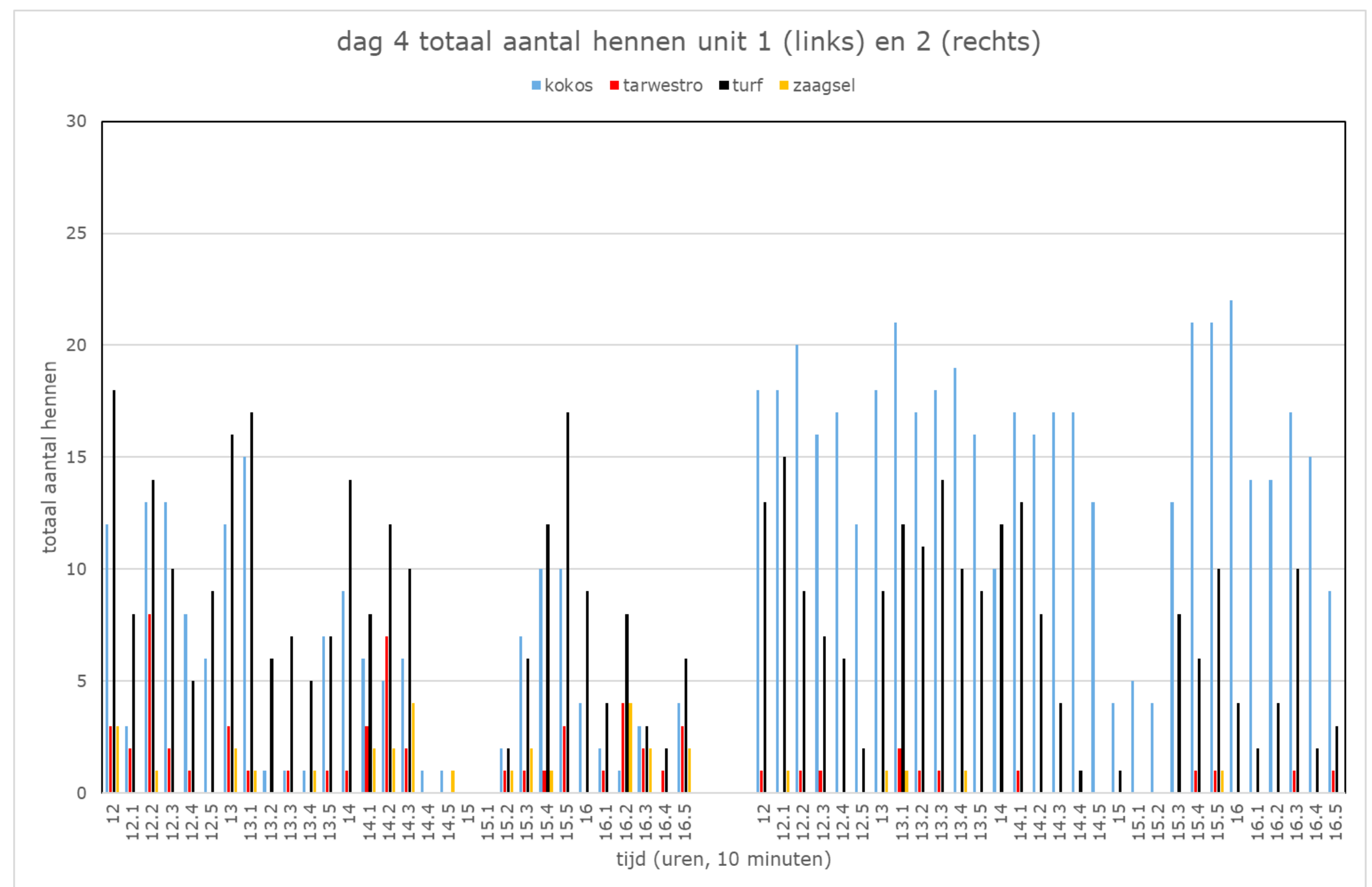

Figuur 4 Totaal aantal aanwezige hennen in de bakken met de verschillende substraten op dag 4 in unit 1 (links) en 2 (rechts). 


\section{Bijlage 2 Aantal stofbadende hennen per dag}

dag 1 stofbaden unit 1 (links) en 2 (rechts)

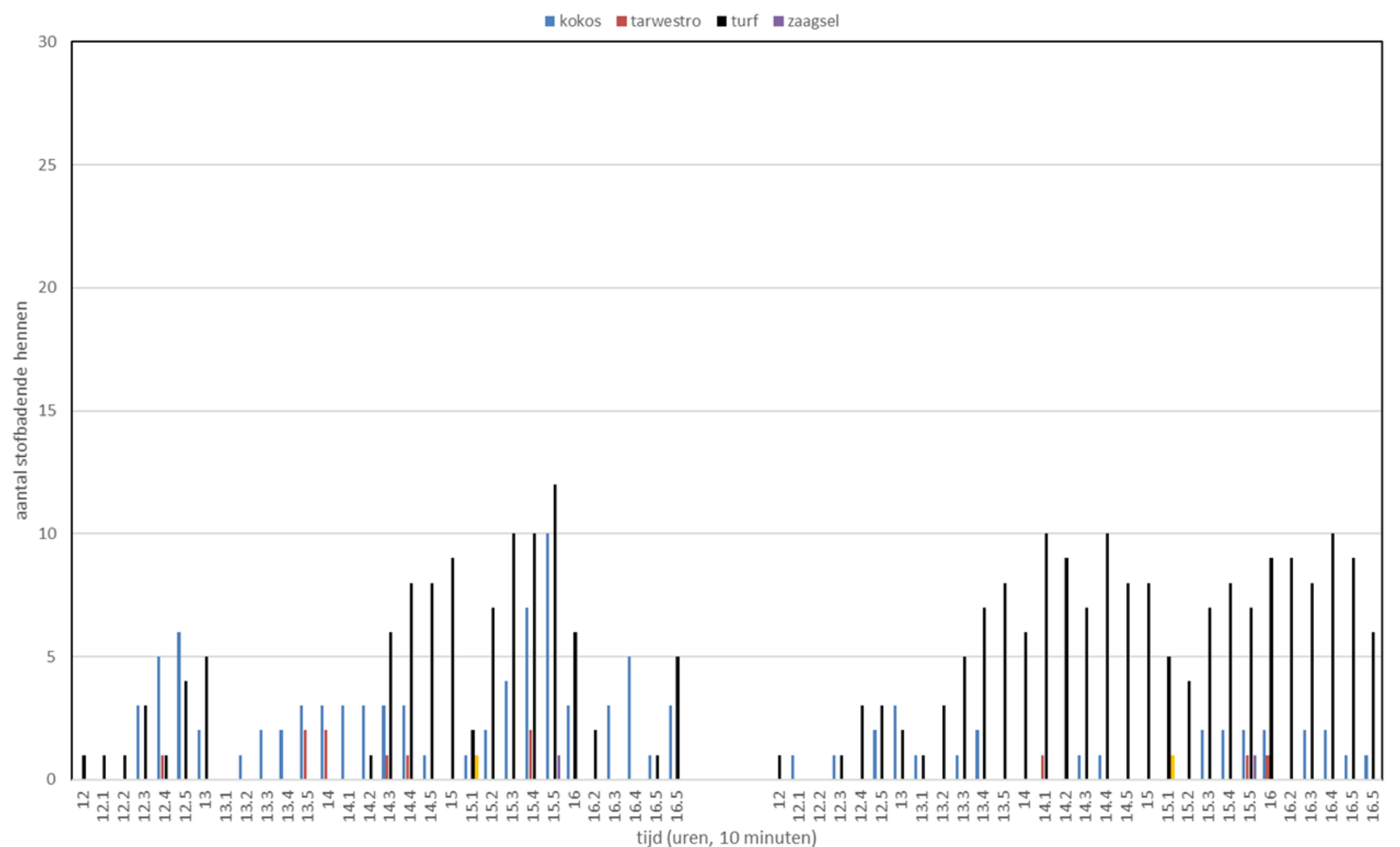

Figuur 5 Aantal stofbadende hennen in de verschillende substraten gedurende op dag 1 van 12.00-17.00 uur in unit 1 (links) en unit 2 (rechts). 


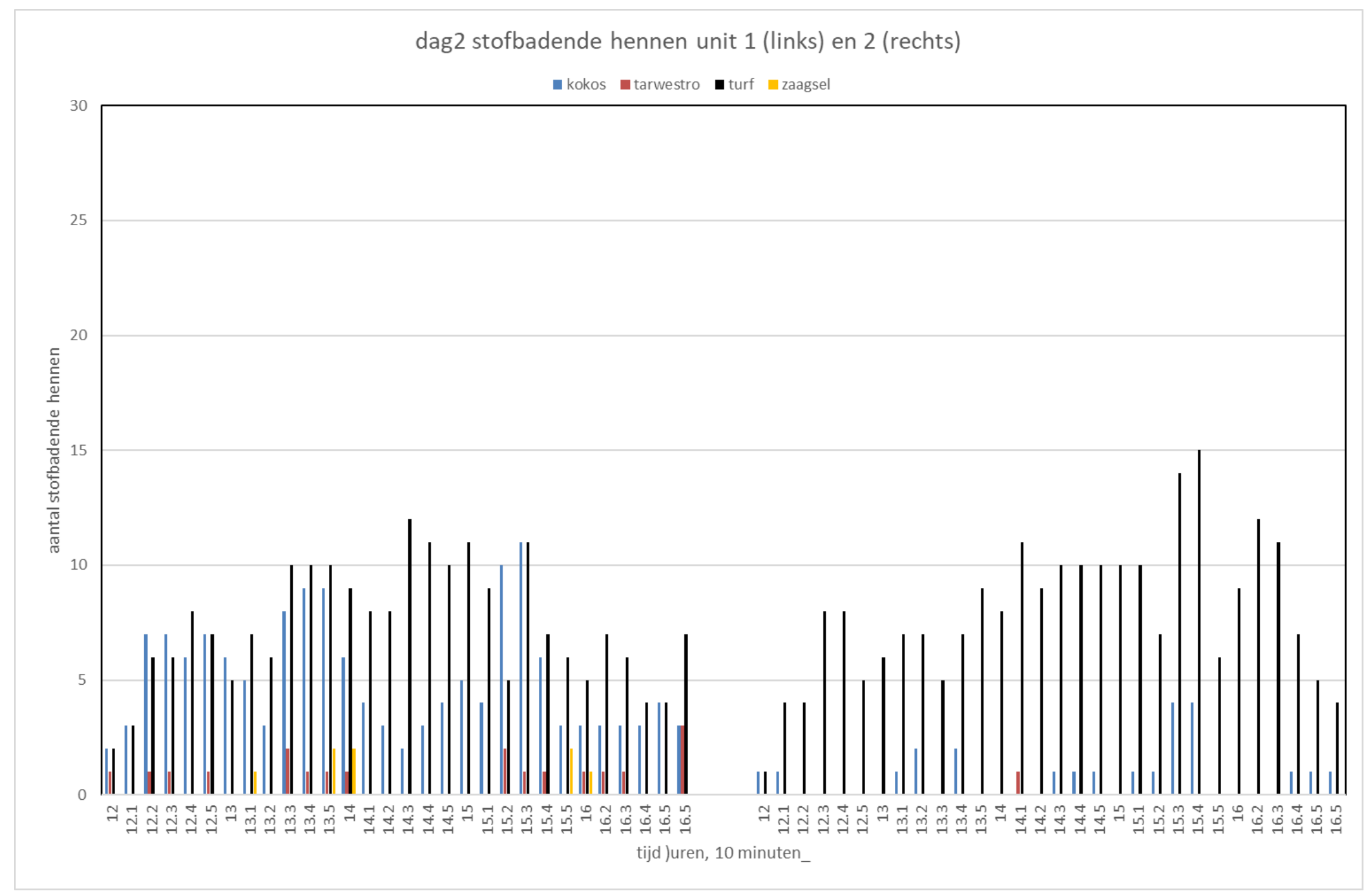

Figuur 6 Aantal stofbadende hennen in de verschillende substraten gedurende op dag 2 van 12.00-17.00 uur in unit 1 (links) en unit 2 (rechts). 
dag 3 stofbadende hennen unit 1 (links) en 2 (rechts)

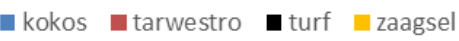

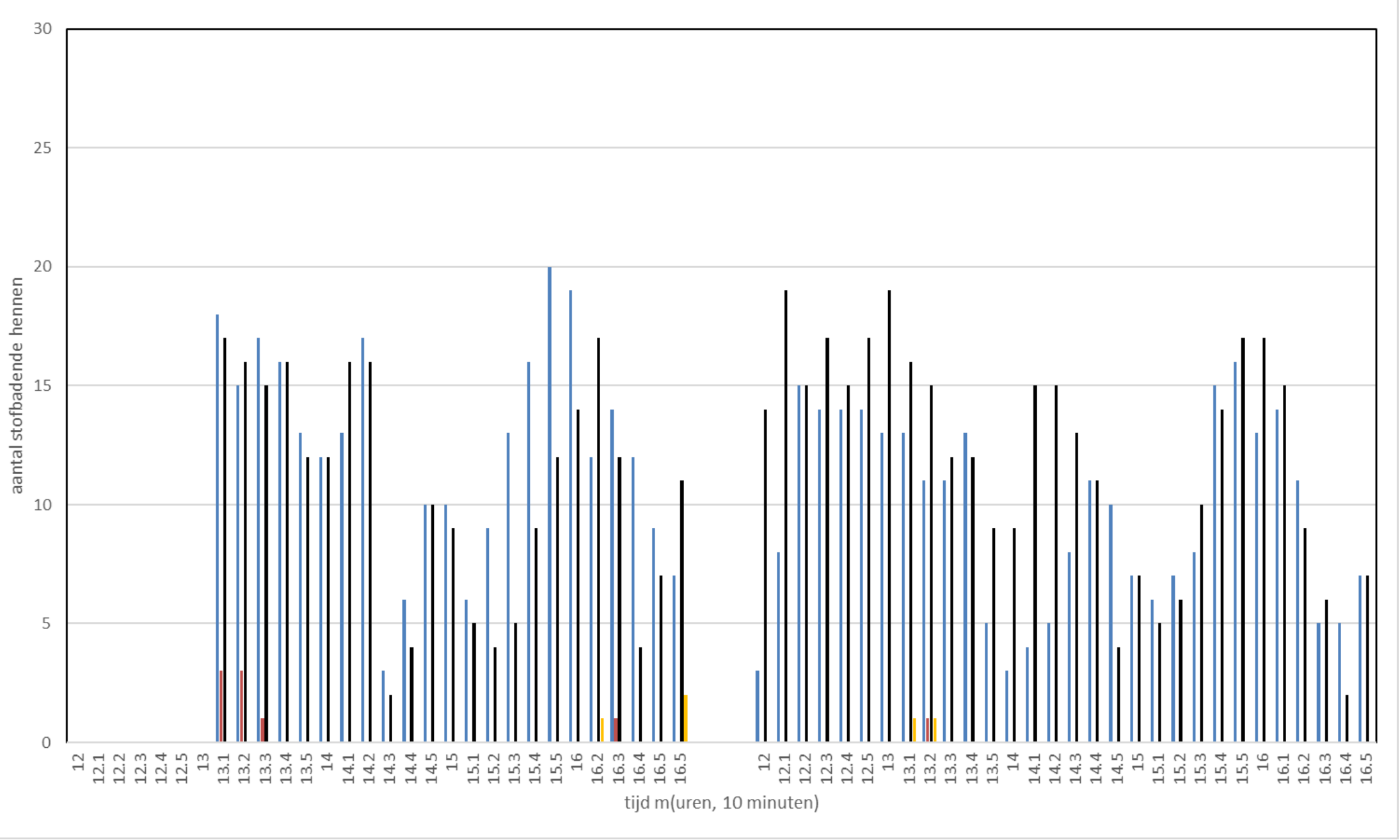

Figuur 7 Aantal stofbadende hennen in de verschillende substraten gedurende op dag 3 van 12.00-17.00 uur in unit 1 (links) en unit 2 (rechts). 


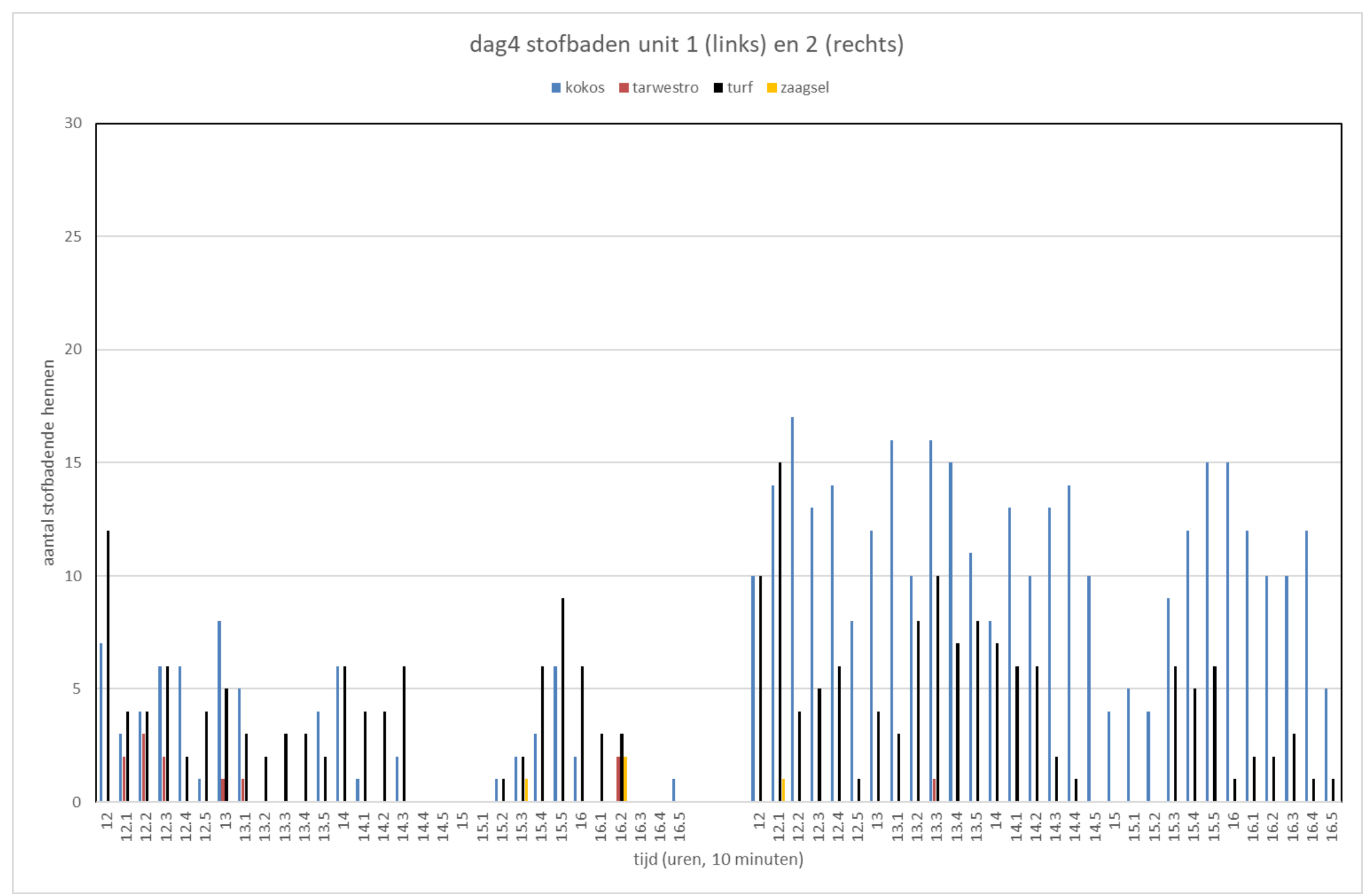

Figuur 8 Aantal stofbadende hennen in de verschillende substraten gedurende op dag 4 van 12.00-17.00 uur in unit 1 (links) en unit 2 (rechts). 


\section{Bijlage 3 Percentage stofbadende hennen per dag}

dag 1 percentage stofbaden unit 1 (links) en 2 (rechts)

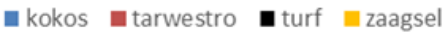

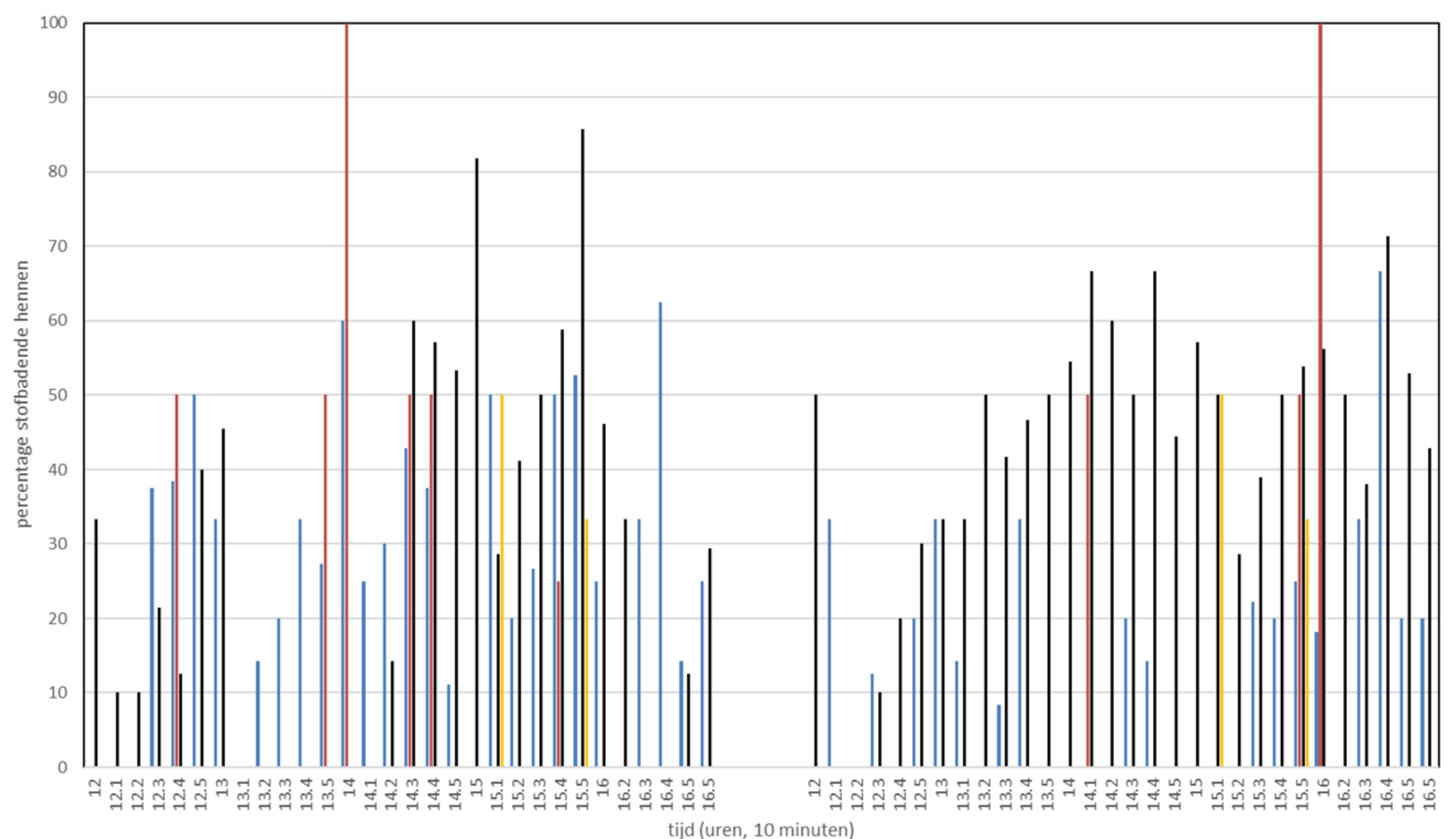

Figuur 9 Percentage stofbadende hennen in de verschillende substraten gedurende dag 1 van 12.00-17.00 uur in unit 1 (links) en unit 2 (rechts). 
dag 2 percentage stofbaden unit 1 (links) en 2 (rechts)

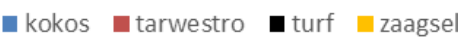

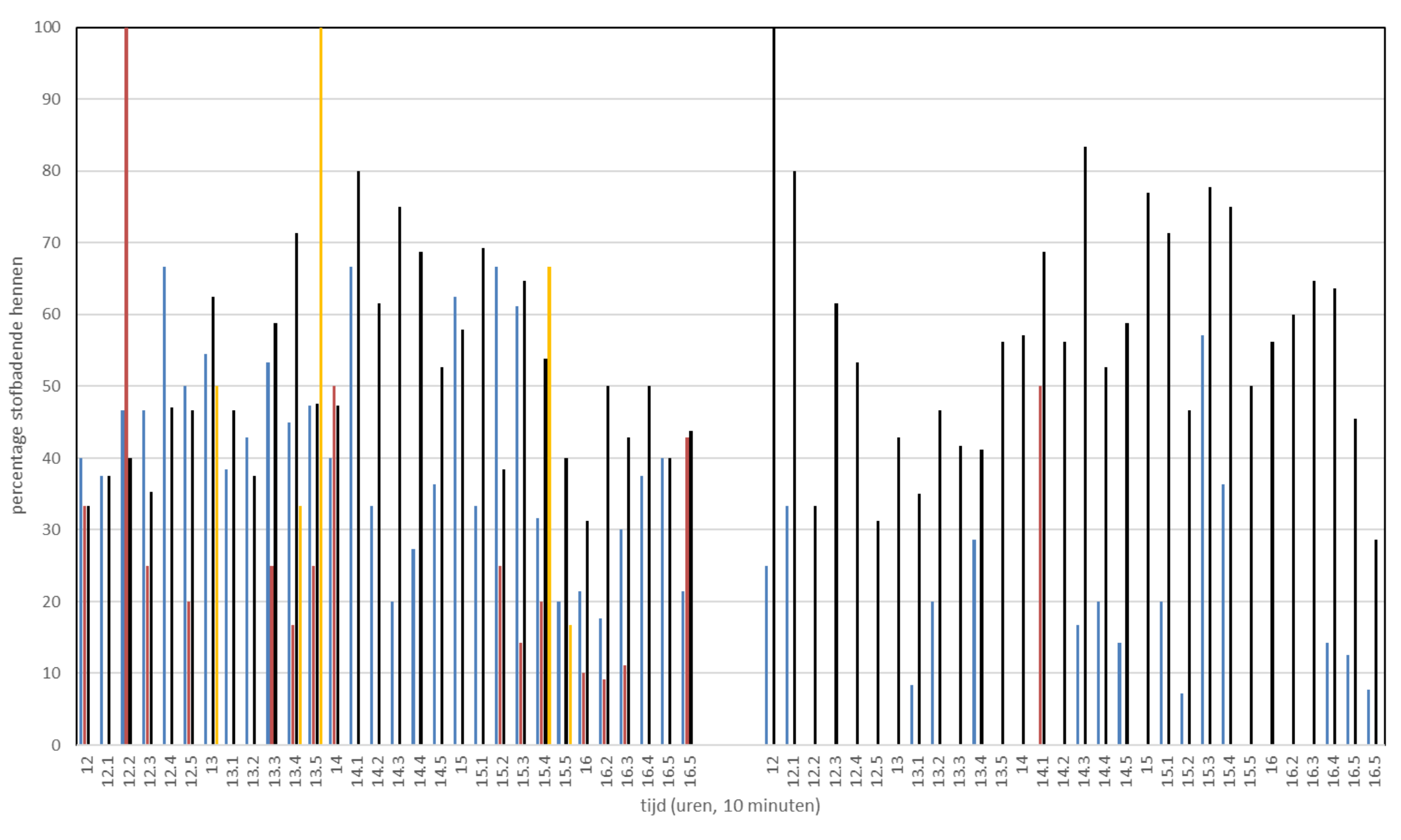

Figuur 10 Percentage stofbadende hennen in de verschillende substraten gedurende dag 2 van 12.00-17.00 uur in unit 1 (links) en unit 2 (rechts). 
dag3 percentage stofbaden unit 1 (links) en 2 (rechts)

- kokos m tarwestro - turf $m$ zaagsel

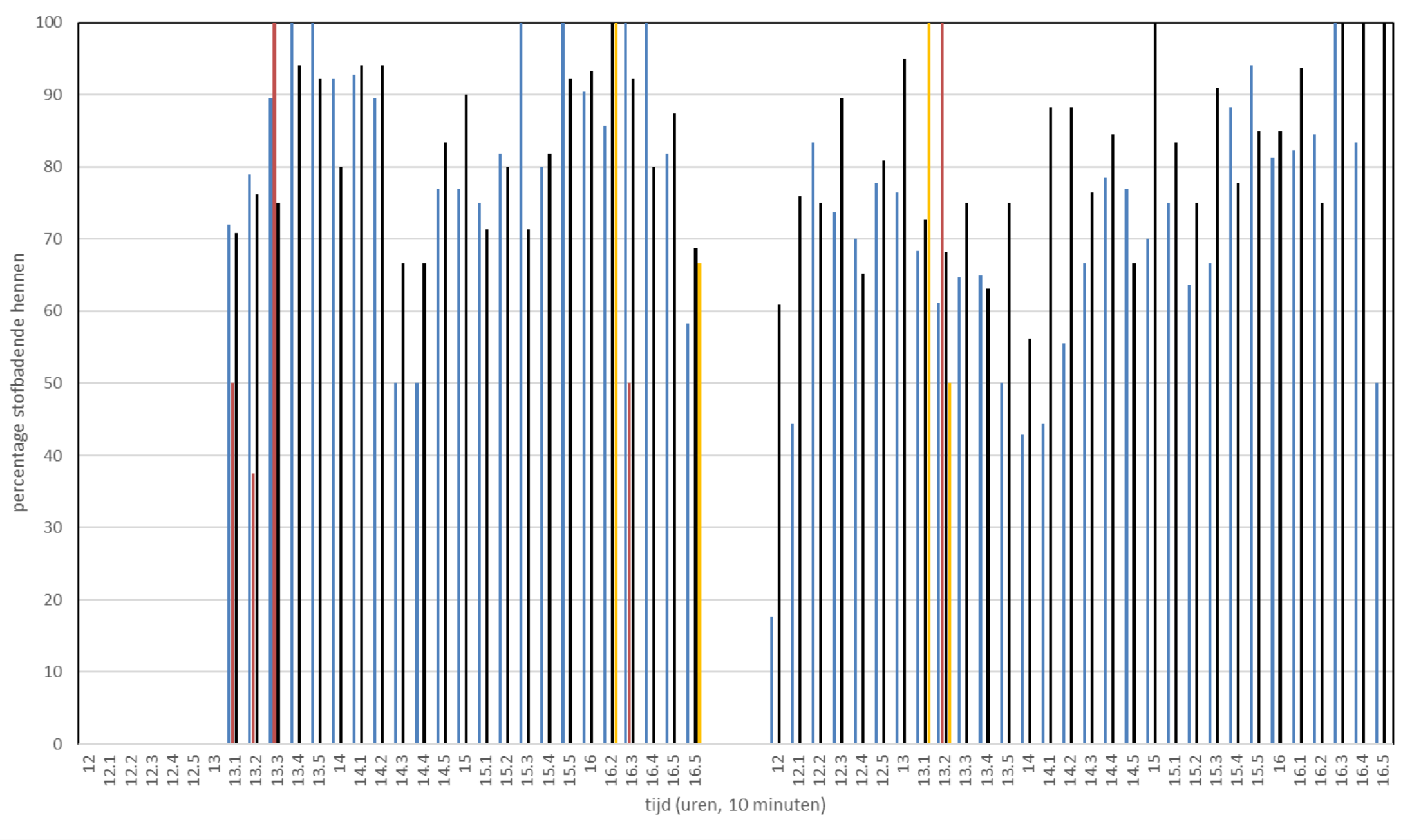

Figuur 11 Percentage stofbadende hennen in de verschillende substraten gedurende dag 3 van 12.00-17.00 uur in unit 1 (links) en unit 2 (rechts). 
dag4 percentage stofbaden unit 1 (links) en 2 (rechts)

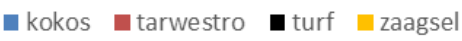

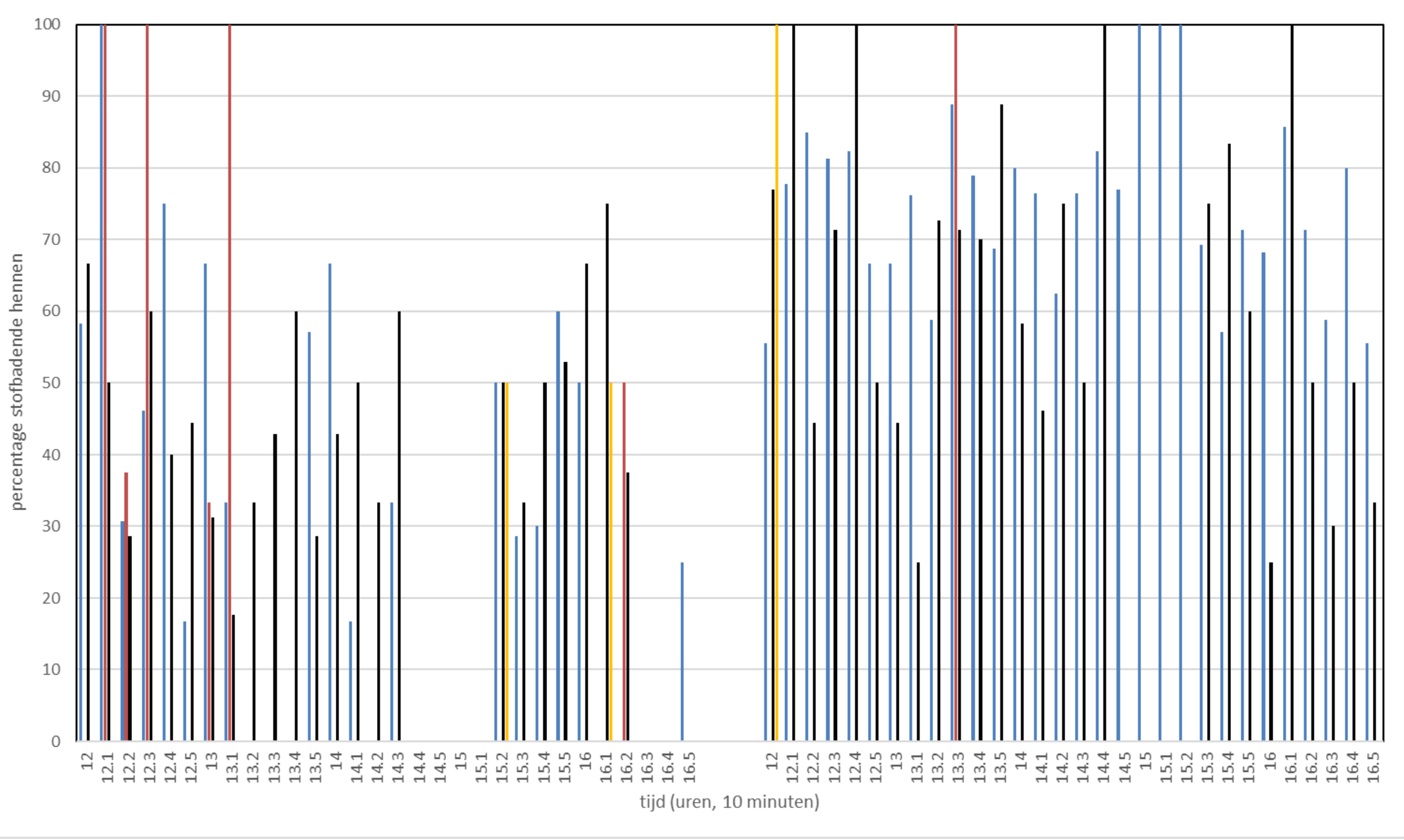

Figuur 12 Percentage stofbadende hennen in de verschillende substraten gedurende dag 4 van 12.00-17.00 uur in unit 1 (links) en unit 2 (rechts). 


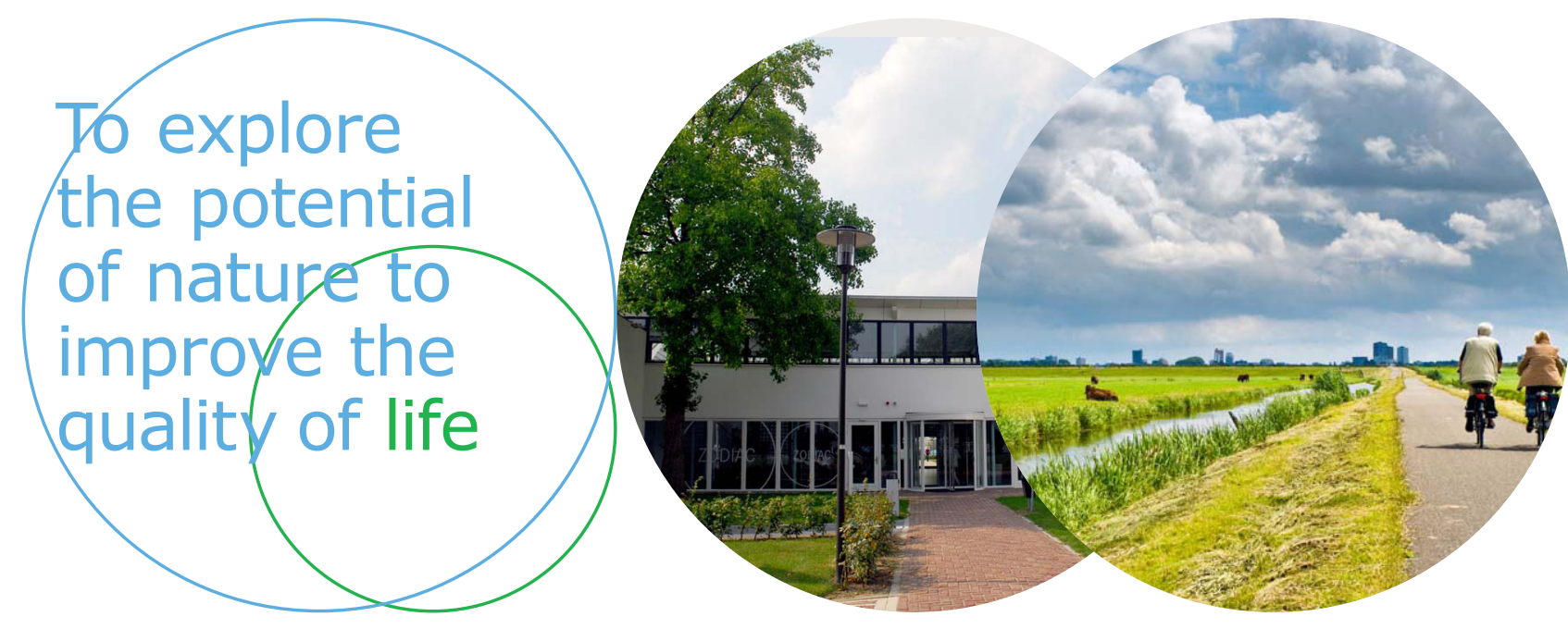

Wageningen Livestock Research Postbus 338

$6700 \mathrm{AH}$ Wageningen

T 0317483953

E info.livestockresearch@wur.nl www.wur.nl/livestock-research
Wageningen Livestock Research ontwikkelt kennis voor een zorgvuldige en renderende veehouderij, vertaalt deze naar praktijkgerichte oplossingen en innovaties, en zorgt voor doorstroming van deze kennis. Onze wetenschappelijke kennis op het gebied van veehouderijsystemen en van voeding, genetica, welzijn en milieu-impact van landbouwhuisdieren integreren we, samen met onze klanten, tot veehouderijconcepten voor de $21 \mathrm{e}$ eeuw.

De missie van Wageningen University \& Research is 'To explore the potential of nature to improve the quality of life'. Binnen Wageningen University \& Research bundelen 9 gespecialiseerde onderzoeksinstituten van Stichting Wageningen Research en Wageningen University hun krachten om bij te dragen aan de oplossing van belangrijke vragen in het domein van gezonde voeding en leefomgeving. Met ongeveer 30 vestigingen, 6.500 medewerkers en 10.000 studenten behoort Wageningen University \& Research wereldwijd tot de aansprekende kennisinstellingen binnen haar domein. De integrale benadering van de vraagstukken en de samenwerking tussen verschillende disciplines vormen het hart van de unieke Wageningen aanpak. 